\title{
Hiperpicnitos (Inunditos) como análogos de reservatórios: um exemplo nos depósitos Gonduânicos Triássicos do Gráben Arroio Moirão, Rio Grande do Sul
}

\author{
Hiperpicnites (Inundites) as reservoir analogs: an example in the \\ Triassic Gondwanic deposits of Arroio Moirão Graben, Rio Grande do Sul
}

\begin{abstract}
Yolanda Caliman Rodrigues ${ }^{1}$ (D), Rualdo Menegat ${ }^{1}$ (D), Ana Maria Pimentel Mizusaki ${ }^{1}$ (D), Aurélio Fagundes Silva ${ }^{1}$ (D) 'Universidade Federal do Rio Grande do Sul - UFRGS, Instituto de Geociências, Curso de Pós-Graduação em Geociências IG/CPGG, Avenida Bento Gonçalves, 9.500, Caixa Postal 15.001, CEP 91501-970, Porto Alegre, RS, BR (yolanda.caliman@ufrgs.br; rualdo.menegat@ufrgs.br; ana.mizusaki@ufrgs.br; aureliofagundes@hotmail.com)
\end{abstract}

Recebido em 5 de fevereiro de 2018; aceito em 29 de outubro de 2019

\begin{abstract}
Resumo
Os arenitos associados a modelos episódicos de inundação, como os Inunditos provenientes de fluxos hiperpicnais em corpos de água rasa, podem ser reservatórios de hidrocarbonetos. No entanto, há poucos estudos para entender a arquitetura e heterogeneidade desses modelos, o que resulta em dificuldades para exploração e explotação desses reservatórios. O presente trabalho visa à análise de pacotes triássicos da Bacia do Paraná pertencentes à Formação Santa Maria, que ocorrem como fragmentos isolados sobre o Escudo Sul-Rio-Grandense na região do Gráben Arroio Moirão (Rio Grande do Sul). Para tanto, fez-se um estudo comparativo de modelos de inundação e como metodologia de obtenção de dados utilizou-se mapeamento sistemático, análise de heterogeneidade de fácies e estratigrafia de sequências, que incluem levantamento de perfis colunares, identificação de associações e sucessões de fácies e superfícies-chave. Secundariamente, algumas análises petrográficas foram realizadas. Foi possível delimitar os principais depósitos de arenitos, dos quais predominam geometria tabular, grãos mal selecionados e alguma matriz argilosa. Distinguiram-se cinco ciclos deposicionais granodecrescentes ascendentes, limitados na base e no topo por superfícies erosivas, que marcam heterogeneidades recorrentes. As fácies-reservatório são subarcósios, de matriz argilosa com agregados de caulinita, porosidade intergranular e shrinkage. Identificaram-se potenciais fácies-reservatório constituídas de arenitos grossos a conglomeráticos, com estratificações cruzada tangencial e plano-paralela. A integração dos dados resultou na elaboração de um modelo de variação lateral e vertical de fácies de hiperpicnitos lacustres, como um potencial modelo análogo de reservatório do tipo compartimentado. Esses resultados possibilitam prospectar outros depósitos arenosos dessa unidade estratigráfica da Bacia do Paraná, para fins de dimensionar regionalmente o análogo de reservatório.
\end{abstract}

Palavras-chave: Bacia do Paraná; Formação Santa Maria; Sequência Candelária; Turbiditos extrabacinais.

\begin{abstract}
Sandstones associated with episodic flooding models, such as inundites from hyperpicnal flows in shallow water bodies, can be hydrocarbon reservoirs. However, there are few studies to understand the architecture and heterogeneity of these models, resulting in difficulties to explore and exploit these reservoirs. The current work aimed to analyze Triassic strata from the Paraná Basin belonging to the Santa Maria Formation, which occur as isolated fragments over the Sul-Rio-Grandense Shield in the region of Arroio Moirão Graben (RS). Thus, a comparative study of flood models was made, as a methodology for data collection, systematic mapping, facies heterogeneity analysis and sequence stratigraphy were used, including columnar profiles survey, identification of facies associations and sequences, and key surfaces. Secondarily, some petrographic analyses were performed. It was possible to define the main deposits of sandstones, in which tabular
\end{abstract}


geometry, poorly selected grains and clay matrix predominate. Five ascending granodecrescent depositional cycles were distinguished, limited at the base and the top by erosive surfaces, which mark recurrent heterogeneities. Reservoir facies are subarkoses, with clay matrix aggregates of kaolinite, intergranular porosity and shrinkage. Potential reservoir facies formed by coarse to conglomerate sandstones with tangential and planar bed cross stratifications were identified. Data integration resulted in the elaboration of a model of lateral and vertical facies variation of lake hyperpicnites, as a potential analogous model of compartmentalized-type reservoir. These results allow the prospection of other sandy deposits from this stratigraphic unit of the Paraná Basin, in order to regionally evaluate the reservoir analogue.

Keywords: Paraná basin; Santa Maria Formation; Candelária sequence; Extrabasinal turbidites.

\section{INTRODUÇÃO}

Depósitos de inundações episódicas estão relacionados ao desenvolvimento de fluxos densos, comuns em condições áridas, em uma diversidade de ambientes, tais como fluviais efêmeros e perenes (McKee et al., 1967; Williams e Kemp, 1971; Leeder, 1999; Miall, 2006). O estudo sistemático das principais inundações mostra que elas podem atingir bacias continentais e marinhas na forma de fluxos de baixa densidade ou hiperpicnais (Zavala et al., 2011; Zavala e Arcuri, 2016). A gênese desses depósitos é atribuída a eventos de tempestade com grande descarga d'água em ambientes continentais, principalmente em cabeceiras de montanhas, nas quais as energias potencial e cinética favorecem a concentração de sedimentos no corpo do fluxo e a rápida elevação do nível de base local (Seilacher, 1991; Della Fávera, 2001; Zavala et al., 2011). Esses são os fatores que propiciam o disparo de fluxos densos, os quais dificilmente aconteceriam em períodos normais de cheias dominadas por fluxos turbulentos de rios (Zavala e Arcuri, 2016).

O modelo de Inundito foi proposto inicialmente, como depósitos relacionados a corpos de água rasa (Seilacher, 1991; Della Fávera, 2001). No entanto, há muitos outros significados para esse termo na literatura. Stricto sensu, são referidos ao processo deposicional de fluxos hiperpicnais, cujos depósitos se assemelham a turbiditos (Zavala et al., 2011; Zavala e Arcuri, 2016). Ou, ainda, é endereçado como um modelo deposicional com sentido predominantemente, geomorfológico, como o terminal splay (Fischer et al., 2008). Lato sensu, está relacionado ao processo de fluxo turbulento com agradação de barras fluviais pela elevação do nível de base (Della Fávera, 2001). Há uma complexidade de processos sedimentares e uma variedade de locus deposicional (desde a base da escarpa até zonas profundas da bacia), tornando necessário esclarecer como depósitos de Inunditos e inundações estão relacionados.

Para o reconhecimento de modelos faciológicos em análise estratigráfica, segue-se, comumente, o pensamento 'Lyelliano', segundo o qual são considerados, para fins de comparação, apenas modelos amplamente estabelecidos e diretamente acessíveis, como os de ambientes continentais.
Inúmeros modelos de Inunditos são analisados sob essa visão uniformitarista e interpretados como modelo 'flúvio-lacustre'. Outros, porém, são menos explorados, como aqueles modelos gerados a partir de fluxos hiperpicnais, desenvolvidos em ambientes de difícil acesso, que exigem técnicas indiretas para a análise do processo de deposição, a exemplo de depósitos de hiperpicnitos. Por essa dificuldade de entendimento, interpreta-se, muitas vezes, a porção de sedimentos grossos de hiperpicnitos como semelhante aos depósitos de canais fluviais, enquanto a porção de sedimentos finos de hiperpicnitos é entendida como semelhante aos depósitos lacustres.

Essas distintas análises - feitas, muitas vezes, para um mesmo tipo de registro - estão relacionadas a sucessões de sedimentos grossos e finos que levam a nomenclatura ambígua de depósitos "flúvio-lacustres", enquanto poderiam ser interpretados como depósitos de hiperpicnitos. Estes podem ocorrer em regiões mais profundas da bacia, como em lagos de domínios de distensão crustal, nos quais se poderia encontrar fragmentos de folhas bem preservados em fácies argilosas, característica diagnóstica de modelos de fluxos de baixa densidade de origem continental (Zavala et al., 2011; Zavala e Arcuri, 2016). No entanto, há de se considerar ainda que a interpretação de depósito flúvio-lacustre contradita com o fato de esses arenitos serem ricos em matriz argilosa. Isso porque sistemas fluviais possuem maior eficiência na segregação de grãos do que os fluxos densos continentais (Leeder, 1999; Zavala e Arcuri, 2016). As ambiguidades na interpretação desses depósitos, aqui apresentadas, geram um impacto direto no estudo de análogos de reservatórios desses modelos.

Torna-se uma questão-chave aprimorar o conhecimento de modelos sedimentares episódicos de inundação (Inunditos), para eventual exploração e explotação de óleo e gás. Os Inunditos (Seilacher, 1991; Della Fávera, 2001) têm sido recentemente identificados nas unidades triássicas isoladas da Bacia do Paraná (BCPR) sobre o Escudo Sul-Rio-Grandense (Lima, 2014; Rodrigues, 2015; Borsa, 2015; Salgado, 2016; Lima et al., 2018. O objetivo do presente artigo é propor uma classificação para os modelos de inundação episódica, conhecidos genericamente como Inunditos, de forma a melhor tipificar as fácies, 
as associações de fácies e os ciclos dos depósitos sedimentares do GAM pertencentes à Sequência Candelária. Especificamente, almeja-se definir como o modelo hiperpicnito lacustre se coloca como potencial análogo de reservatório de petróleo e gás.

\section{Aspectos geológicos e estratigráficos da área de estudo}

A BCPR, localizada na região sul-sudoeste do Brasil, oeste do Paraguai, nordeste da Argentina e norte do Uruguai, com área aproximada de $1.500 .000 \mathrm{~km}^{2}$, é uma ampla sinéclise que se consolidou inicialmente na forma de depressões alongadas na direção NE-SW, segundo a trama e zonas de fraqueza do substrato pré-cambriano, comportando seis supersequências deposicionais de segunda ordem, do Ordoviciano ao Cretáceo Superior (Milani, 1997; Milani e Zalán, 1999; Milani et al., 2007) (Figura 1).
Em um contexto de distensão generalizada na porção sul do paleocontinente Gondwana, formou-se a Supersequência Gondwana II, com sequências sedimentares do Triássico Médio ao Superior (Uliana e Biddle, 1988 apud Milani et al., 2007).

Novos termos estratigráficos para a Supersequência Gondwana II foram propostos por Zerfass (2003), como a Supersequência Santa Maria, subdividida em três sequências de terceira ordem denominadas como Santa Maria I, II e III. O conteúdo fossilífero contido na Supersequência Santa Maria está relacionado à paleofauna de tetrápodes e à flora Thinfeldia-Dicroidium que ocorrem em unidades estratigráficas da Argentina e da África do Sul (Faccini et al., 1990; Barberena et al., 1991; Soares et al., 2011). A partir desses fósseis, várias propostas de biozoneamento foram feitas, entre elas a Cenozona de Rincossauros, pertencente à sequência Santa Maria II (Carniano/Noriano) (Zerfass, 2003).

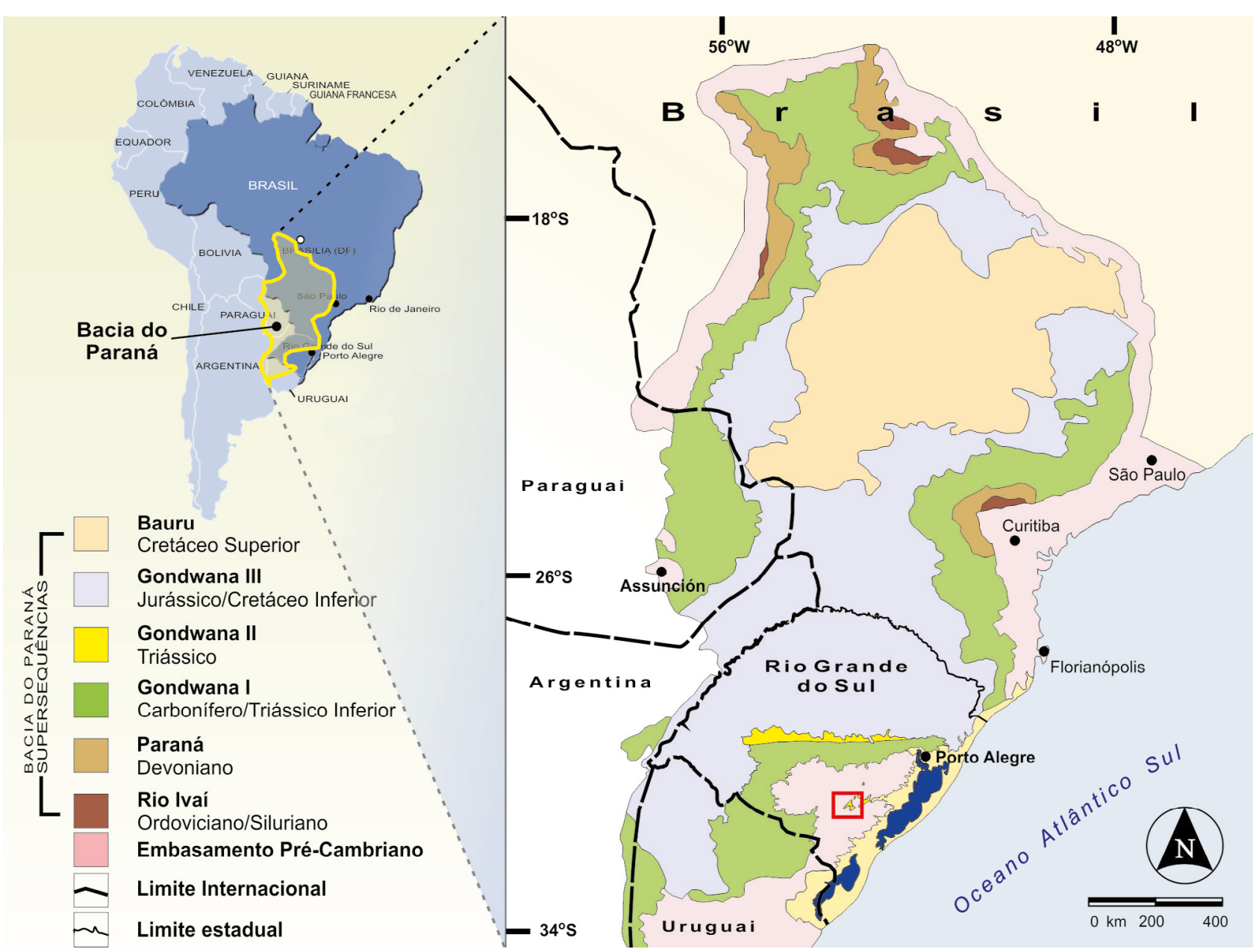

Fonte: modificado de Milani et al. (2007).

Figura 1. Mapa de localização da área de estudo, destacada pelo quadrado vermelho, e contexto estratigráfico da Bacia do Paraná. 
Posteriormente, uma quarta unidade e novos nomes para as sequências de terceira ordem foram sugeridos e a sequência Santa Maria II foi renomeada como Sequência Candelária (Figura 2) (Horn et al., 2014). A Sequência Candelária foi correlacionada com a ocorrência isolada da região do GAM, que ocorre de forma descontínua à BCPR (Faccini et al., 1990; Horn et al., 2015). O gráben localiza-se entre as cidades de Canguçu e Santana da Boa Vista (Rio Grande do Sul) e compreende a área de estudo descrita neste artigo. A unidade triássica do GAM está assentada sobre unidades metamórficas do Neoproterozoico Superior, na porção central do Cinturão Dom Feliciano no Escudo-Sul-Rio-Grandense (Figura 3).

\section{Evolução dos modelos deposicionais do Triássico Sul-Rio-Grandense}

Foram propostos inúmeros modelos deposicionais para a área estudada. Inicialmente, foi utilizado o termo 'Formação Santa Maria' (Gordon, 1947 apud Faccini, 2000) para designar as rochas sedimentares de cor vermelha, contendo vertebrados fósseis, limitadas por discordâncias. Outra denominação para o pacote triássico da BCPR foi de Formação Rosário do Sul (Gamermann, 1973), considerada como o registro de um sistema deposicional flúvio-lacustre constituído, na base, pela "Fácies Fluvial" arenosa, correspondendo a canais fluviais e planície de inundação e, no topo, pela 'Fácies

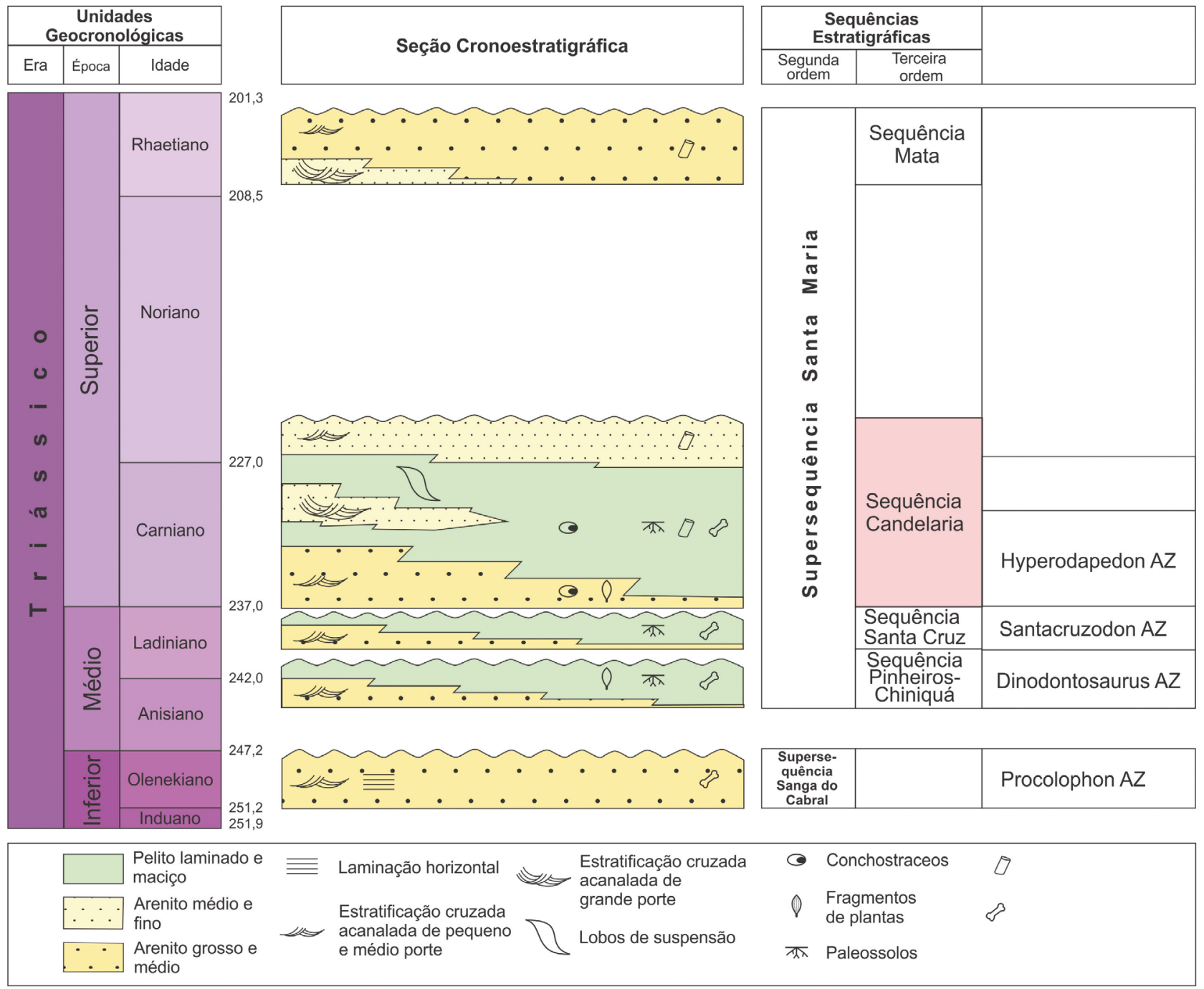

Figura 2. Cronoestratigrafia do Triássico do Sul do Brasil com biozonas de vertebrados, modificado de: (A) Supersequência: Zerfass et al. (2003); Milani et al. (2007); (B) sequências: Zerfass (2003); Horn et al. (2014); (C) biozonas: Soares et al. (2011). Em destaque, a Sequência Candelária que indica o posicionamento estratigráfico do pacote sedimentar do GAM. 
Santa Maria' (sensu Morais Rego, 1930 apud Faccini, 2000), caracterizada por depósitos pelíticos, vermelhos, com fósseis da fauna triássica associada a corpos lacustres descontínuos como uma fácies subordinada ao grande sistema fluvial Rosário do Sul.

Posteriormente, a Fm. Santa Maria foi individualizada (Bortoluzzi, 1974) em Fácies Passo das Tropas, basal, areno-conglomerática, de origem fluvial com fragmentos da flora Thinfeldia-Dicroidium e Fácies Alemoa, lamítica, vermelho alaranjada com vertebrados fósseis.

A última estruturação litoestratigráfica reuniu as unidades triássicas no Grupo Rosário do Sul (Andreis et al., 1980 apud Faccini, 2000), o qual tinha, na base, os arenitos fluviais da Formação Sanga do Cabral (anterior Fm. Rosário do Sul), esta posicionada entre o Permiano Superior e a base do Triássico Médio; seguida pela Fm. Santa Maria (do Triássico Médio e Superior), cujo membro Alemoa foi interpretado como depósito loessico, devido à ausência de estruturas nos pelitos e por interpretações semelhantes em depósitos atuais argentinos; no topo, a Fm. Caturrita, com arenitos fluviais pertencentes ao Triássico Superior.

A primeira análise aloestratigráfica (Faccini, 2000) para os depósitos triássicos resultou nas seguintes subdivisões: Sequência I - Fm. Rio do Rasto (Permiano) e Fm. Sanga do Cabral (transição Permiano-Triássico) formadas em ambientes lacustre, deltaico, fluvial e eólico; Sequência II - constituída dos membros da Fm. Santa Maria, Passo das Tropas (depósitos fluviais) e Alemoa (depósitos lacustres e deltaicos), e por parte da Fm. Caturrita (depósitos fluviais); e Sequência III - composta por "arenitos Mata" (Faccini, 1989), porção superior da Fm. Caturrita (Andreis et al., 1980 apud Faccini, 2000), de origem fluvial com acumulações alóctones de caules silicificados de coníferas e também por outros depósitos de frentes deltaicas lacustres e de crevasse splays, portadores de vertebrados fósseis da Fm. Caturrita.

Como proposta de subdivisão aloestratigráfica de $2^{\mathrm{a}}$ ordem (Milani et al., 2007), o Triássico Sul-Rio-Grandense foi subdivido nas Supersequências: Gondwana I, contendo a Fm. Sanga do Cabral, que representaria a conjunção de alguns sistemas continentais e lacustres; e Gondwana II, que ocorreu como uma transgressão lacustre sobre o topo da discordância da supersequência anterior. Essa relação de transgressão no topo da discordância levou à interpretação de que regionalmente estabeleceu-se um rebaixamento acelerado do substrato com o desenvolvimento de uma bacia faminta. Na Supersequência Gondwana II, desenvolveu-se um ambiente de subsidência com a formação de
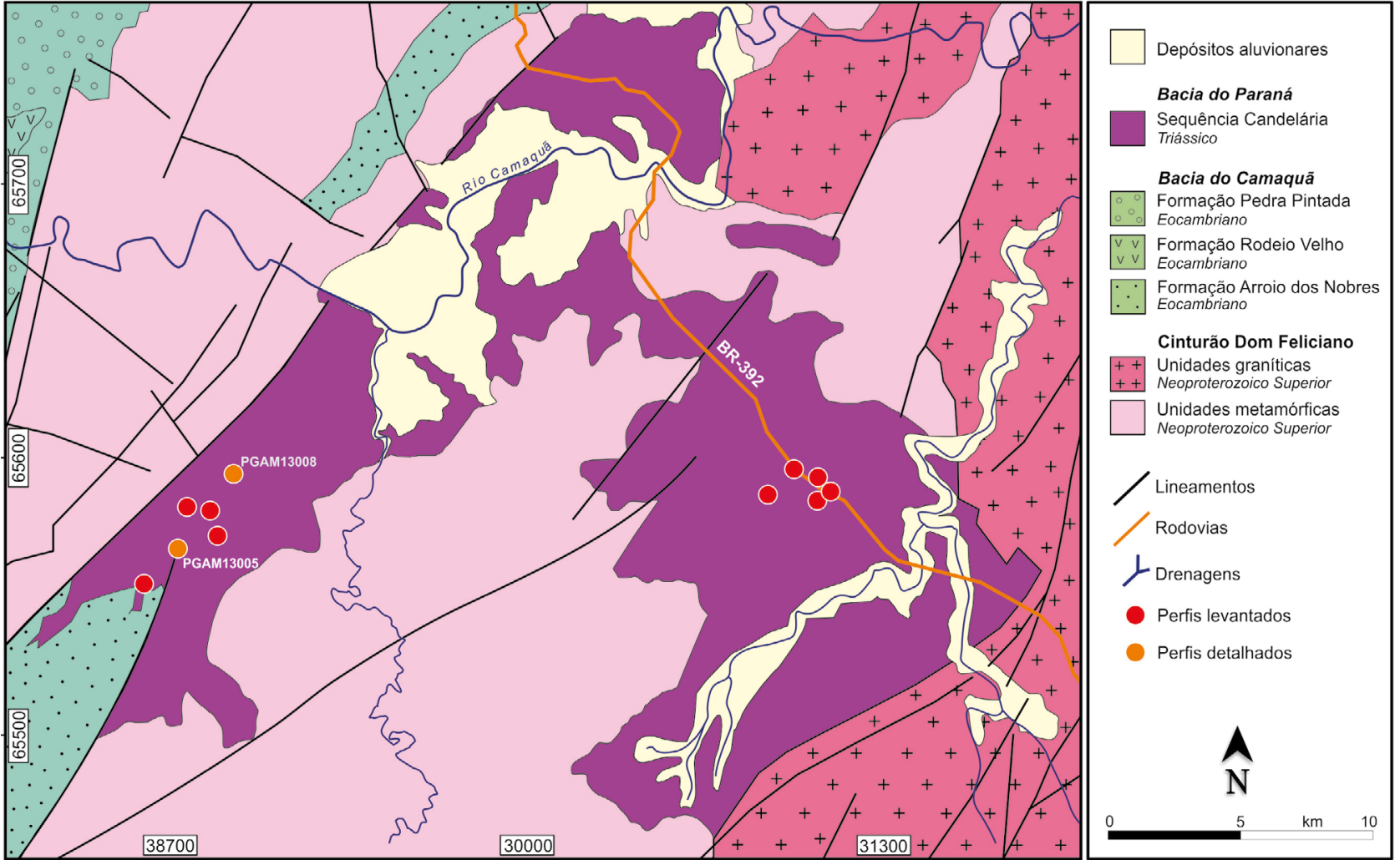

Fonte: Wildner et al. (2005).

Figura 3. Mapa geológico do GAM, contendo os depósitos da Sequência Candelária, e localização de perfis da área de estudo. 
grábens distensivos assimétricos, em que se acomodava a drenagem fluvial sobre a rampa flexural desse sistema, com desenvolvimento de depósitos pelíticos nos lagos dessas regiões subsidentes (Milani et al., 2007). Também foi documentada a ciclicidade nesses registros sedimentares pela intercalação de pelitos lacustres e arenitos fluviais, como uma resposta à variação do nível de base lacustre pelo controle tectono-climático (Milani e Ramos, 1998). Nessa região, além da deposição de pelitos, houve progradações arenosas marcando a transição do que viria a ser o sistema dominante na Supersequência Gondwana III (Milani et al., 2007).

Outra proposição de sequência de segunda ordem para o Triássico foi a de Supersequência Sanga do Cabral (Zerfass et al., 2003), interpretada como resultante de depósitos de canais não confinados desenvolvidos em planícies aluviais de baixo gradiente em ambiente com baixo espaço de acomodação. Considerou-se que a deposição tenha ocorrido durante eventos de flash flood, desenvolvidos sob condições áridas ou semiáridas, associada à deposição dentro de pequenos lagos, pela existência de intercalação de lentes de lamito laminado. Foram encontrados ossos fossilizados de anfíbios, o que representaria fases curtas mais úmidas associadas a lagos perenes.

As Sequências II e III (Faccini, 2000) correspondem à Supersequência Gondwana II (Milani e Ramos, 1998) e à Supersequência Santa Maria (Zerfass et al., 2003), que são de segunda ordem. As Sequências Santa Maria I, II e III (Zerfass et al., 2003) são de $3^{\mathrm{a}}$ ordem. Na Sequência Santa Maria I, foram identificadas:

- Associação de fácies de barras cascalhosas e elementos arquiteturais de formas de leito arenosas atribuída a rios de baixa sinuosidade e alta energia. Esses depósitos também foram associados a deltas frontais em lagos rasos;

- Associação de fácies de sedimentos grossos a mais finos foi abruptamente recoberta por argilito depositado acima de uma superfície de inundação, considerada como uma superfície transgressiva.

Assim, houve alternância de estações secas e úmidas, e os depósitos fluviais e deltaicos seriam de trato de sistema de nível baixo. Na Sequência Santa Maria II, os depósitos fluviais foram exclusivamente relacionados ao trato de sistema de nível baixo. A intercalação de lentes de pelito com arenitos fluviais foi interpretado como depósitos de inundação. Os pelitos representariam a deposição em lagos de águas rasas. No trato de sistema transgressivo foi incluído um pacote eólico, de um provável campo de dunas eólicas, interpretado como indicativo de uma mudança climática. Esses depósitos foram sucedidos por outros lacustres-deltaicos. Também foram identificados corpos de arenito amalgamados, em lentes estreitas maciças ou estratificadas, vinculados a canais de alta relação largura/profundidade. Houve a substituição progressiva da bacia lacustre por um sistema fluvial pela redução do espaço de acomodação. Por sua vez, a Sequência Santa Maria III também foi interpretada como de sistema fluvial, além de elementos arquiteturais de fluxo de gravidade (lentes de diamictito intraformacional intercalados com arenitos) como um produto de fluxos gravitacionais gerados por terraços fluviais em colapso, em trato de sistema de nível baixo.

Portanto, os pacotes sedimentares da BCPR pertencentes à Formação Santa Maria foram interpretados, inicialmente, como modelos "flúvio-lacustres" (Gamermann, 1973; Andreis et al., 1980), fluviais, deltaicos e lacustres (Faccini, 2000; Zerfass et al., 2003). Somente na década de 2010 novos modelos foram propostos, como os de: Inunditos (Lima, 2014; Rodrigues, 2015; Borsa, 2015; Salgado, 2016; Lima et al., 2018), fluviais efêmeros (Horn, 2016; Horn et al., 2018) e terminal splay (Borsa et al., 2017). Embora esses trabalhos tenham reconhecido depósitos de inundação, nenhum deles estabeleceu de forma detalhada a relação entre associações de fácies e seus mecanismos de distribuição. Neste artigo, propõe-se, de forma inédita, que os depósitos da Sequência Candelária do GAM representam vários ciclos de um modelo de hiperpicnito, este bem especificado por Zavala et al. (2011). Além disso, mostra-se como esse modelo se enquadra no espectro de possibilidades de depósitos denominados genericamente de Inunditos (Seilacher, 1991; Della Fávera, 2001). Dessa maneira, procura-se avançar na descrição e no entendimento de modelos que têm sido descritos na literatura de forma geral como "Inunditos" ou "flúvio-lacustres".

\section{MÉTODOS}

Para a identificação e caracterização de um modelo robusto de Inundito e seus estratos arenosos, como um análogo de reservatório, fez-se, primeiramente, um levantamento de todos os modelos gerados por inundações, a sua classificação quanto ao tipo de fluxo, processo deposicional e estruturas geomorfológicas, para a proposição de uma tabela que sintetizasse todos esses conceitos. Os principais métodos utilizados no levantamento de dados deste trabalho e seus principais produtos são enumerados a seguir:

- Mapeamento sistemático para o reconhecimento da área de estudo (Stow, 2005; Coe, 2010; Lisle et al., 2014; Tucker, 2014) e identificação das porções mais arenosas dos pacotes sedimentares aflorantes no gráben, relacionados à Sequência Candelária; 
- Técnicas de análise de fácies (Walker, 1992; Dalrymple, 2010; James e Dalrymple, 2010) e descrição de 20 afloramentos e 11 perfis colunares;

- Levantamento de detalhe de dois perfis colunares (PGAM13-005 e PGAM13-008), por serem os mais representativos de litologias arenosas, dos quais foram interpretados 20 fácies e 7 sucessões de fácies;

- Identificação de modelos deposicionais de acordo com técnicas de Potter e Pettijohn (1977), Miall (1999) e Einsele (2000);

- Caracterização de fácies em cinco lâminas petrográficas para análises de composição e porosidade secundária (sensu Terry e Chilingar, 1955; Folk, 1968; Tucker, 2001);

- Identificação de cinco ciclos deposicionais (CD), por agrupamentos faciológicos que mostram agradações ou retrogradações repetidos de maneira cíclica nos perfis, caracterizando as heterogeneidades em macroescala de hiperpicnitos como análogo de reservatórios;

- Montagem e análise de cinco fotomosaicos dos perfis colunares de detalhe, para a avaliação de geometrias de fácies-reservatório e extensionalidades;

- Identificação de superfícies-chave - ou seja, de relevância estratigráfica — que representem uma mudança de processos sedimentares em uma associação de fácies ou, ainda, que representem superfícies regionais de erosão, interferindo na preservação de todo um intervalo de sedimentação;

- Definição de sequências deposicionais e suas correlações regionais utilizando-se de superfícies-chave ou camadas-chave.

Os conceitos de estratigrafia de sequências foram readaptados a partir de interpretações feitas anteriormente nas sequências flúvio-lacustres da Supersequência Santa Maria (sensu Zerfass et al., 2003). Assim, a estratigrafia de sequências (Catuneanu, 2006) permite a definição de um arcabouço estratigráfico, em termos de unidades fundamentais de sequências genéticas de deposição, limitadas por suas discordâncias limítrofes e conformidades correlativas.

\section{RESULTADOS}

\section{Modelos de Inunditos}

O termo Inundito é utilizado na literatura para caracterizar amplo espectro de depósitos originados por inundações. Contudo, os mecanismos principais de transporte e deposição, bem como de morfologia desses depósitos, não têm sido bem especificados. Existe uma falta de clareza entre o uso do termo inundação como processo geral e os modelos faciológicos de Inunditos, o que torna necessário apresentar uma análise do conceito de Inunditos, por meio de um estudo comparativo da literatura. Além disso, discutem-se, aqui, as características geomorfológicas e os processos deposicionais dos diferentes modelos de inundação e depósitos episódicos.

Quais são as estruturas e os significados dos Inunditos? Os modelos são agrupados em duas categorias principais (Tabela 1):

- Depósitos de inundações, predominantemente subaéreos, subdivididos em sistemas perenes (com ou sem formação de lagos efêmeros) e em sistemas efêmeros (com lago efêmero presente ou ausente);

- Predominantemente depósitos subaquáticos, rasos ou profundos. As principais características distintivas de cada categoria e subcategoria são definidas para seis modelos selecionados.

Lato sensu, Inunditos são identificados como um intervalo anômalo de deposição na sucessão de fácies de um modelo estabelecido, ou seja, de um modelo perene. Nessa classe, os subdomínios são considerados tanto em sistemas fluviais perenes quanto em leques aluviais. O registro sedimentar está ligado à elevação abrupta do nível de base, o que gera uma anomalia agradacional na deposição de barras fluviais ou mesmo hiperpicnitos em lagos efêmeros nas depressões adjacentes aos lobos dos leques aluviais.

Mas, stricto sensu, os Inunditos são identificados como um modelo deposicional episódico de sucessão de fácies completa, que podem se originar de inundações de tempestade (flash flood) associadas a rios intermitentes que se diversificam de acordo com a dispersão de fluxos densos a jusante. Por um lado, o fluxo pode terminar, de modo desconfinante, sobre leitos secos, dando origem ao modelo de "leque terminal" (terminal fan, Kelly e Olsen, 1993). Por outro lado, o fluxo pode se espalhar nas planícies baixas, formando playas e lagos efêmeros (Postma, 2014), dando origem a modelos como o "espraiamento terminal" (terminal splay, Fischer et al., 2008).

Contudo, quando o fluxo é suficientemente denso, pode alcançar corpos d'água rasos (Della Fávera, 2001), baías protegidas (Seilacher, 1991) e até mesmo ambiente marinho profundo (Zavala et al., 2011; Zavala e Arcuri, 2016). Nesses casos, ao desembocar em corpos d'água como fluxo hiperpicnal, desenvolve depósitos semelhantes aos de turbidito clássico (Mutti et al., 1992). Nesse compasso, o modelo distinto denominado "turbidito extrabacinal" ou também "hiperpicnito" estabeleceu a natureza do processo deposicional desses fluxos subaquosos hiperpicnais e as correspondentes sucessões e associações de fácies (Zavala et al., 2011; Zavala e Arcuri, 2016). Uma de suas características é a origem exclusivamente continental dos turbiditos extrabacinais provocados por chuvas episódicas ou sazonais, com 
grandes descargas de água e lama, que conferem a esse fluxo singular uma densidade superior à da bacia receptora (Figura 4). Essa característica permite o seu deslocamento inercial próximo ao leito por centenas de quilômetros. É particularmente singular nesses fluxos o processo de flotação (lofting), ou seja, a segregação de mica ou de fragmentos vegetais e folhas por plumas de suspensão que ficam concentrados em níveis em meio aos sedimentos finos nas regiões mais distais e profundas da bacia (Zavala e Arcuri, 2016).

\section{Análise de fácies, processos deposicionais e associação de fácies}

De modo geral, as fácies dos pacotes sedimentares do GAM apresentam geometria tabular, coloração avermelhada, granulometria mal selecionada, composição quartzo-feldspática. Parâmetros como geometria de camadas, textura, estrutura sedimentar e paleocorrente, bem como conteúdo fossilífero, foram utilizados para a identificação de 20 fácies, cujas abreviaturas, descrições e interpretação do processo deposicional encontram-se relacionadas nas Tabelas 2, $3 \mathrm{e}$ 4 e nas Figuras 5, 6 e 7. Com base nesses parâmetros de análise de fácies pôde-se agrupá-las de acordo com os processos hidrodinâmicos de sua formação. Considerando-se um fluxo de composição mista, de cascalho a lama, as fácies puderam ser agrupadas em três associações geneticamente relacionadas: associação faciológica proximal de carga de leito (AFL), associação de fácies mediana de carga de suspensão (AFS) e associação de fácies distal de depósitos de flotação (AFF). Esses depósitos resultaram da configuração de correntes hiperpicnais e da perda de competência do fluxo. Essas associações de fácies correspondem àquelas do modelo de distribuição faciológica proposto por Zavala et al. (2011) e Zavala e Arcuri (2016) (Figura 4).

\section{Associação de fácies proximal de carga de leito}

Caracteriza-se por fácies de granulação grossa de carga de leito, comumente com geometrias tabularoides, coloração avermelhada, matriz de areia muito fina ou argilosa, gradação normal intraestratal, granulometricamente mal selecionado, intraclastos de tamanho seixo a bloco de composição argilosa a arenítica muito fina. Recorrente superfície erosiva na base dos sets, com subsequente preenchimento por canais rasos. A imbricação de clastos é comum, como indicativo de fluxo do tipo newtoniano, em que os clastos podem rotar livremente. Essa característica é distintiva de um fluxo hiperpicnal quando comparado ao modelo de turbidito clássico ou intrabacinal, pois, nesses casos, não há possibilidade de imbricação de clastos (Mutti et al., 1992). Essa associação, que representa canais rasos de progradação inicial de fluxos hiperpicnais, é constituída das subassociações de fácies L1, L2 e L3 (Tabela 2, Figura 5), como detalhado a seguir:

- Subgrupo de Fácies L1: fácies de conglomerados de estrutura maciça, abundante matriz, sem indicador aparente da forma de leito, regime de fluxo inferior. Interpretada como resultante de fluxos rápidos de transição de baixa densidade para tração, produzindo depósitos de progradação de carga de leito e formação de pavimentos.

- Subgrupo de fácies L2:

a) fácies com estratificação cruzada tangencial de pequeno a grande porte, ou em sets festonados, representando leitos dunoides 3D, em regime de fluxo inferior. Foram interpretadas como:

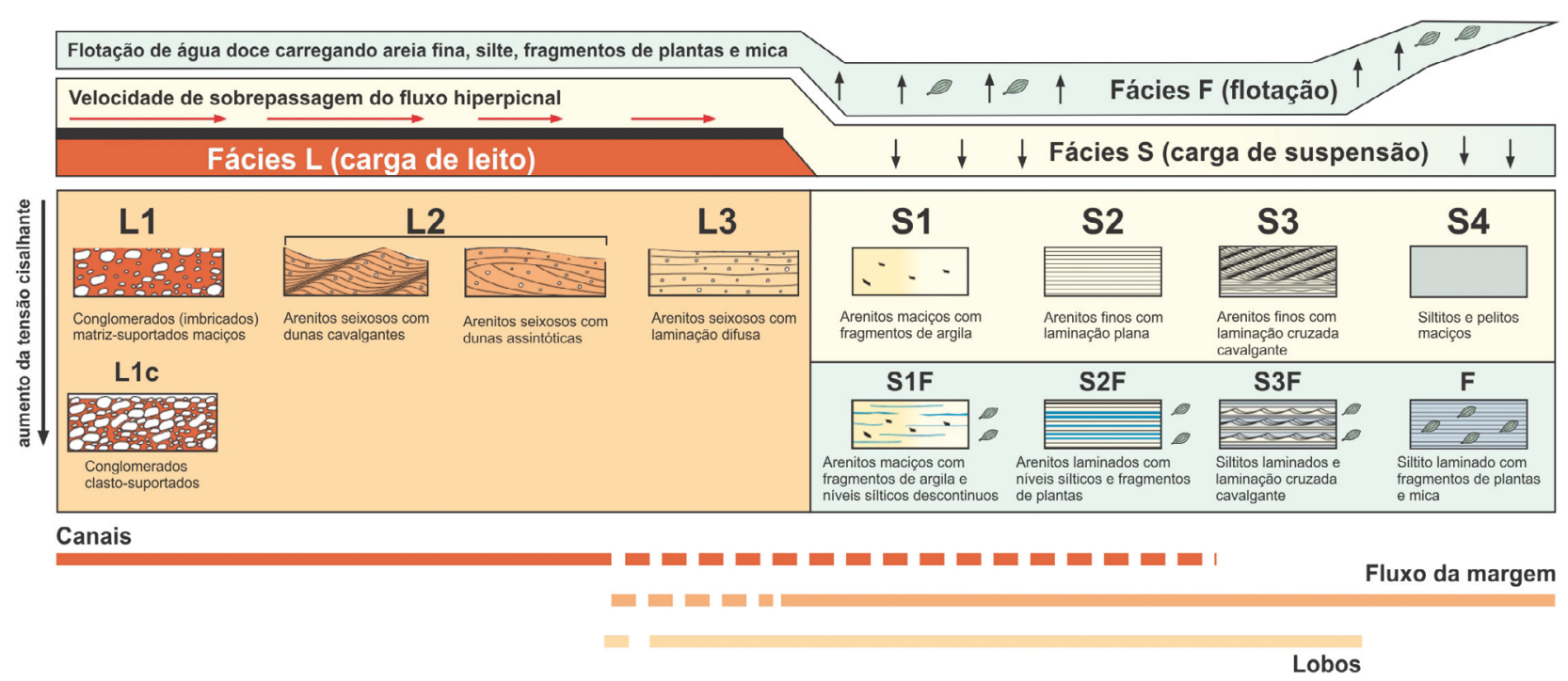

Fonte: modificado de Zavala et al. (2011).

Figura 4. Modelo de distribuição das associações e subgrupos de fácies de fluxos hiperpicnais 
a1)arenitos conglomeráticos com processo de segregação textural em fluxos de baixa densidade e transição para correntes trativas formando fácies de progradação de carga de leito em canais;

a2) arenito muito grosso a grosso com processos de correntes trativas de desaceleração de fluxo formando fácies de preenchimento de canais;

b) fácies de arenito grosso com estratificação cruzada plano-paralela, de médio porte, representando leitos dunoides $2 \mathrm{D}$, em regime de fluxo inferior, interpretada como resultante de processos de correntes subaquosas trativas de desaceleração de fluxos de baixa densidade, formando associação de fácies de canais. Este subgrupo de fácies é constituinte importante dos análogos de reservatórios.

- Subgrupo de fácies L3:

a) fácies de arenito conglomerático a médio com laminação plano-paralela, representando formas de leitos tabulares. Foram interpretadas como resultantes de processos de: dispersão de fluxos de regime de fluxo inferior, originados por depósitos de canais rasos por uma combinação do efeito da deposição de carga de fundo e posterior segregação de clastos ou intraclastos pela passagem do fluxo turbulento;

b) fácies de arenito grosso com estratificação cruzada de baixo ângulo representando formas de leitos dunoides 2D, interpretada como resultante de processos de correntes trativas de rápida dispersão, originando depósitos de canais rasos. Este subgrupo de fácies é constituinte importante dos análogos de reservatórios.

\section{Associação de fácies mediana de carga de suspensão}

Caracteriza-se por fácies de carga de suspensão de granulação fina, representando comumente geometrias

Tabela 1. Tipos de Inunditos, principais modelos e características.

\begin{tabular}{|c|c|c|c|c|c|}
\hline \multicolumn{3}{|c|}{ Tipos de Inundito } & Exemplo & \multicolumn{2}{|l|}{ Características } \\
\hline \multirow{4}{*}{ 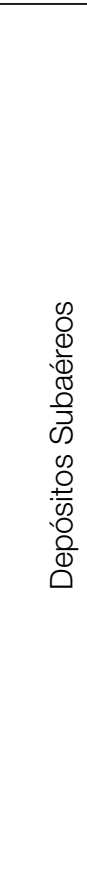 } & \multirow{2}{*}{$\begin{array}{l}\text { Em sistemas } \\
\text { perenes } \\
\text { [modelos } \\
\text { fluviais ou } \\
\text { aluviais] }\end{array}$} & $\begin{array}{l}\text { Lago } \\
\text { efêmero } \\
\text { ausente }\end{array}$ & $\begin{array}{l}\text { Inundito comum } \\
\text { Della Fávera, } 2001 .\end{array}$ & $\begin{array}{l}\text { Fluxos episódicos com carga de fundo/suspensão } \\
\text { com agradação expressiva em modelo perene } \\
\text { Depósitos e barras expressivos; Camadas de } \\
\text { inundação; Subida expressiva do NB por inundação } \\
\text { em sistemas fluviais }\end{array}$ & \\
\hline & & $\begin{array}{l}\text { Lago } \\
\text { efêmero } \\
\text { presente }\end{array}$ & $\begin{array}{l}\text { Inundação em leques } \\
\text { aluviais com lago } \\
\text { efêmero distal } \\
\text { Heward, 1978; } \\
\text { Della Fávera, 2001 }\end{array}$ & $\begin{array}{l}\text { Fluxo gravitacional episódico em canais alimentadores } \\
\text { e distributários de modelo perene; Hiperpicnito em } \\
\text { corpos rasos } \\
\text { Barras em canais distributarios; Inundação em lençóis } \\
\text { distais; Depósitos de finos nas porções distais do } \\
\text { leque; Exposição do topo do depósito recém-formado }\end{array}$ & \\
\hline & \multirow{2}{*}{$\begin{array}{l}\text { Em sistemas } \\
\text { efêmeros } \\
\text { [formação } \\
\text { modelos } \\
\text { próprios] }\end{array}$} & $\begin{array}{l}\text { Lago } \\
\text { efêmero } \\
\text { eventual }\end{array}$ & $\begin{array}{l}\text { Terminal fan } \\
\text { Kelly e Olsen, } 1993 . \\
\text { Rios efêmeros } \\
\text { arenosos e Inundações } \\
\text { relâmpago } \\
\text { Miall, 2006. }\end{array}$ & $\begin{array}{c}\text { Correntes com carga de fundo/suspensão em } \\
\text { regime de fluxo inferior e superior } \\
\text { Bifurcação do canal principal em rede de } \\
\text { canais e microcanais em planície tipo braided; } \\
\text { alta evaporação e infiltração e baixas taxas de } \\
\text { precipitação; Dunas e lençóis eólicos intercalados; } \\
\text { Planícies salinas, evaporitos }\end{array}$ & \\
\hline & & $\begin{array}{l}\text { Lago } \\
\text { efêmero } \\
\text { presente }\end{array}$ & $\begin{array}{l}\text { Terminal Splay } \\
\text { Fischer et al., } 2008 .\end{array}$ & $\begin{array}{l}\text { Desaceleração de carga de fundo de canais fluviais } \\
\text { em lagos efêmeros } \\
\text { Canais distributários proximais e lobos de } \\
\text { desconfinamento aberto; Lençol de inundação sobre } \\
\text { leitos secos ou lagos efêmeros }\end{array}$ & \\
\hline \multirow{2}{*}{\multicolumn{2}{|c|}{$\begin{array}{l}\text { Depósitos } \\
\text { subaquosos } \\
\text { [modelo turbidítico] }\end{array}$}} & $\begin{array}{l}\text { Água rasa } \\
\text { lago ou } \\
\text { baía }\end{array}$ & $\begin{array}{l}\text { Inundito Clássico } \\
\text { Seilacher, } 1991 . \\
\text { Turbidito raso } \\
\text { Della Fávera, } 2001 .\end{array}$ & $\begin{array}{c}\text { Hiperpicnito corpos aquosos rasos } \\
\text { Semelhante a turbidito; Marcas de raízes e superfície } \\
\text { de ressecamento; Camadas plano-paralelas de } \\
\text { arenitos e folhelhos, ritmitos }\end{array}$ & \\
\hline & & $\begin{array}{l}\text { Água } \\
\text { profunda } \\
\text { lago ou } \\
\text { mar }\end{array}$ & $\begin{array}{c}\text { Hiperpicnitos } \\
\text { Zavala et al., 2011; } \\
\text { Zavala e Arcuri, } 2016 .\end{array}$ & $\begin{array}{l}\text { Hiperpicnito corpos aquosos profundos; semelhante a } \\
\text { turbidito; Origem extrabacinal }\end{array}$ & \\
\hline
\end{tabular}


tabulares ou lençoides, coloração avermelhada, granulometricamente mal selecionado, intraclastos de tamanho seixo (até $4 \mathrm{~cm}$ ), charcoal, muscovita dispersa. Essa associação de fácies corresponde à desaceleração de fluxo turbulento rico em areia, em canais rasos, e é constituída pelos subgrupos de fácies S1, S2 e S4 (Tabela 3, Figura 6), com processos geradores detalhados a seguir.
- Subgrupo de fácies s1: fácies cujas texturas variam de arenito médio a muito fino de estrutura maciça, sem indicador aparente da forma de leito. Foi interpretada como resultante de provável deposição em zona de transição agradacional, caracterizada por grande concentração de sedimentos e escape de fluidos. Outra interpretação possível é a acumulação por colapso gradual de areia de granulação mais fina proveniente de fluxo turbulento;

Tabela 2. Associação de fácies proximal de carga de leito (AFL): fácies, grupos e interpretação dos processos deposicionais.

\begin{tabular}{|c|c|c|c|}
\hline Grupo & Código & Descrição & Interpretação \\
\hline L1 & $\mathrm{Cg} / \mathrm{Gr}(\mathrm{m})$ & $\begin{array}{c}\text { Conglomerado granuloso e arenoso maciço, avermelhado, mal } \\
\text { selecionado, com blocos esparsos ( } \varphi \text { máx }=20 \mathrm{~cm} \text { ) e intraclastos de } \\
\text { arenito fino. }\end{array}$ & $\begin{array}{l}\text { Corrente trativa, regime de } \\
\text { fluxo inferior, sem eviência da } \\
\text { forma de leito. }\end{array}$ \\
\hline \multirow{6}{*}{ L2 } & $\begin{array}{l}\mathrm{Ag}(\mathrm{cpp}) \\
\mathrm{mp}\end{array}$ & $\begin{array}{l}\text { Arenito grosso, com estratificação cruzada plano-paralela de médio } \\
\text { porte (mp) e gradação normal intraestratal; avermelhado, quartzo- } \\
\text { feldspático. Mal selecionado, seixos de quartzo angulosos dispersos, } \\
\text { mica e fração fina significativa (cerca de } 5 \%) \text {. }\end{array}$ & $\begin{array}{l}\text { Corrente trativa, regime de } \\
\text { fluxo inferior, dunas } 2 \mathrm{D} \text {. }\end{array}$ \\
\hline & $\begin{array}{l}\mathrm{Ag}(\mathrm{t}) \mathrm{gp}, \\
\mathrm{nS} \times / \mathrm{Gr}\end{array}$ & $\begin{array}{l}\text { Arenito grosso com estratificação cruzada tangencial de grande porte } \\
\text { e gradação normal intraestratal, avermelhado, quartzo-feldspático. } \\
\text { Seixos e grânulos, marcando os planos de estratificação. Níveis } \\
\text { centimétricos de siltito com laminação plano-paralela. }\end{array}$ & $\begin{array}{l}\text { Corrente trativa, regime de } \\
\text { fluxo inferior, dunas 3D. }\end{array}$ \\
\hline & $\mathrm{Ag} / \mathrm{S} x(\mathrm{t})$ & $\begin{array}{c}\text { Arenito grosso seixoso com estratificação cruzada tangencial, } \\
\text { gradação normal intraestratal, avermelhado, quartzo-feldspático. } \\
\text { Intraclastos argilosos ( } \varphi \text { máx }=8 \mathrm{~cm}) \text { na base dos sets, "mud drapes", } \\
\text { pavimento basal seixoso. }\end{array}$ & $\begin{array}{l}\text { Corrente trativa, regime de } \\
\text { fluxo inferior, dunas } 3 \mathrm{D} \text {. }\end{array}$ \\
\hline & $\begin{array}{l}\mathrm{Ag}(\mathrm{t}) \mathrm{f} \\
\mathrm{nSx} / \mathrm{Gr}\end{array}$ & $\begin{array}{c}\text { Sets festonados (f) de arenito grosso, com estratificação cruzada } \\
\text { tangencial e gradação normal intraestratal, avermelhado, quartzo- } \\
\text { feldspático. Mal selecionado, com fração de } 5 \% \text { de argila e grãos } \\
\text { dispersos de areia fina e muito grossa. Níveis de seixos e grânulos } \\
(\mathrm{nS} / \mathrm{Gr} \text { ) e intraclastos argilosos ( } \varphi \text { máx }=10 \mathrm{~cm}) \text {. }\end{array}$ & $\begin{array}{l}\text { Corrente trativa, regime de } \\
\text { fluxo inferior, dunas 3D. }\end{array}$ \\
\hline & $\underset{\operatorname{Gr}(t)}{\operatorname{Acg} / S x-}$ & $\begin{array}{l}\text { Arenito conglomerático seixoso a granuloso, com estratificação } \\
\text { cruzada tangencial e gradação normal intraestratal, avermelhado, } \\
\text { quartzo-feldspático. Mal selecionado (fração de areia fina a silte). } \\
\text { Níveis e lentes de grânulos e seixos ( } \varphi \text { máx }=4 \mathrm{~cm} \text { ). Intraclastos } \\
\text { argilosos de até } 54 \mathrm{~cm} .\end{array}$ & $\begin{array}{l}\text { Corrente trativa, regime de } \\
\text { fluxo inferior, dunas 3D. }\end{array}$ \\
\hline & Amg(t) & $\begin{array}{l}\text { Arenito muito grosso com estratificação cruzada tangencial, } \\
\text { gradação normal intraestratal, cor laranja-clara, quartzo-feldspático } \\
\text { e com mica, mal selecionado, com areia fina e grânulos. Níveis de } \\
\text { seixos na base da estratificação. }\end{array}$ & $\begin{array}{l}\text { Corrente trativa, regime de } \\
\text { fluxo inferior, duna 3D. }\end{array}$ \\
\hline \multirow{4}{*}{ L3 } & $\mathrm{Ag}(\mathrm{lpp})$ & $\begin{array}{l}\text { Arenito grosso, com laminação plano-paralela, avermelhado, quartzo- } \\
\text { feldspático. }\end{array}$ & $\begin{array}{l}\text { Corrente trativa, fluxo inferior, } \\
\text { forma de leito plana. }\end{array}$ \\
\hline & $\begin{array}{l}\mathrm{Ag} / \mathrm{Sx}- \\
\mathrm{Gr}(\mathrm{lpp})\end{array}$ & $\begin{array}{l}\text { Arenito grosso, seixoso a granuloso, com laminação plano-paralela } \\
\text { e gradação normal intraestratal, avermelhado, quartzo-feldspático, } \\
\text { imaturo, mal selecionado, grânulos e seixos muito angulosos, } \\
\text { moderada esfericidade, de quartzo e feldspato. Intraclastos argilosos } \\
\text { ( } \varphi \text { máx }=18 \mathrm{~cm}) \text {. }\end{array}$ & $\begin{array}{l}\text { Corrente trativa, fluxo inferior, } \\
\text { forma de leito plana. }\end{array}$ \\
\hline & $\begin{array}{l}\text { Acg/Sx- } \\
\text { Gr (lpp) }\end{array}$ & $\begin{array}{c}\text { Arenito conglomerático, seixoso a granuloso, avermelhado, } \\
\text { com laminação plano-paralela e gradação normal intraestratal, } \\
\text { pavimento basal de seixos de quartzo e, por vezes, intraclastos } \\
\text { argilosos de até } 6 \mathrm{~cm} \text {. }\end{array}$ & $\begin{array}{l}\text { Corrente trativa, fluxo } \\
\text { inferior, forma de leito plana. }\end{array}$ \\
\hline & $\begin{array}{l}\mathrm{Ag} / \mathrm{Sx}- \\
\mathrm{Gr}(\mathrm{bxa})\end{array}$ & $\begin{array}{l}\text { Arenito grosso a seixoso com estratificação cruzada tabular de baixo } \\
\text { ângulo, avermelhado, quartzo-feldspático, com grânulos quartzosos } \\
\text { esparsos. Com diques clásticos de areia muito grossa sobressalentes. }\end{array}$ & $\begin{array}{l}\text { Corrente, regime trativo de } \\
\text { fluxo inferior, forma de leito } \\
\text { 2D. }\end{array}$ \\
\hline
\end{tabular}


- Subgrupo de fácies s2: fácies de arenitos finos a muito finos com laminação plano-paralela ou de baixo-ângulo, representando formas de leito tabulares interpretadas como resultantes de processos de diluição unidirecional de fluxos em regime superior, originando depósitos em desconfinamento de canais rasos. A laminação milimétrica, por vezes, está marcada por níveis delgados de mica;

- Subgrupo de fácies s4: fácies de siltito com estrutura maciça, sem indicador aparente da forma de leito, interpretada como resultante de processos do limite suspensão/tração. A fácies origina-se por depósitos de plumas de suspensão quando o fluxo para completamente. Consequentemente, a fácies S4 é usualmente identificada no limite entre diferentes eventos de fluxos hiperpicnais.

\section{Associação de fácies distal de flotação}

Essa associação é constituída pelos subgrupos de fácies $\mathrm{F}$ e S2F (Tabela 4, Figura 7), com processos geradores detalhados a seguir.

Tabela 3. Associação de fácies mediana de carga de suspensão (AFS): fácies, grupos e interpretação dos processos deposicionais.

\begin{tabular}{|c|c|c|c|}
\hline Grupo & Código & Descrição & Interpretação \\
\hline \multirow{4}{*}{ S1 } & Amf(m) & $\begin{array}{l}\text { Arenito muito fino, maciço, rosado a avermelhado, quartzo-feldspático. } \\
\text { mal selecionado, com grãos de areia média a grossa esparsos. Por } \\
\text { vezes: grânulos e seixos quartzosos dispersos; intraclastos ( } \varphi \text { máx = } \\
44 \mathrm{~cm} \text { ); matéria carbonosa. }\end{array}$ & $\begin{array}{l}\text { Desaceleração abrupta } \\
\text { de fluxo, corrente trativa, } \\
\text { regime de fluxo inferior, sem } \\
\text { evidência da forma de leito. }\end{array}$ \\
\hline & $\operatorname{Af}(m)$ & $\begin{array}{c}\text { Arenito fino maciço, avermelhado, quartzo-feldspático. mal } \\
\text { selecionado, com grãos dispersos de areia muito grossa, grânulos e } \\
\text { seixos ( } \varphi \text { máx }=1 \mathrm{~cm}) \text {. }\end{array}$ & $\begin{array}{c}\text { Desaceleração abrupta de } \\
\text { fluxo, corrente subaquosa } \\
\text { trativa, regime de fluxo } \\
\text { inferior, sem evidência da } \\
\text { forma de leito. }\end{array}$ \\
\hline & $A m(m)$ & $\begin{array}{l}\text { Arenito médio maciço, avermelhado, quartzo-feldspático. Com grãos } \\
\text { angulosos, por vezes, subangulosos, com moderada esfericidade. } \\
\text { Muitas vezes é mal selecionado, com porções de areia muito grossa. }\end{array}$ & $\begin{array}{l}\text { Desaceleração abrupta de } \\
\text { fluxo, corrente subaquosa } \\
\text { trativa, regime de fluxo } \\
\text { inferior, sem evidência da } \\
\text { forma de leito. }\end{array}$ \\
\hline & $\mathrm{Ag}(\mathrm{m})$ & $\begin{array}{l}\text { Arenito grosso maciço, avermelhado, quartzo-feldspático. Mal } \\
\text { selecionado, fração fina argilosa e intercalações centimétricas de } \\
\text { arenito fino e lentes de siltito. Grãos angulosos a subangulosos. Seixos } \\
\text { de quartzo esparsos. Pavimento de intraclastos e seixos quartzosos. }\end{array}$ & $\begin{array}{l}\text { Desaceleração abrupta } \\
\text { de fluxo, corrente trativa, } \\
\text { regime de fluxo inferior, sem } \\
\text { evidência da forma de leito. }\end{array}$ \\
\hline S2 & Af(Ipp) & $\begin{array}{l}\text { Arenito fino com laminação plano-paralela, avermelhado, quartzo- } \\
\text { feldspático e com mica marcando a laminação. }\end{array}$ & $\begin{array}{l}\text { Corrente trativa, regime de } \\
\text { fluxo superior, forma de } \\
\text { leito plana. }\end{array}$ \\
\hline S4 & $\mathrm{St}(\mathrm{m})$ & $\begin{array}{l}\text { Siltito maciço, avermelhado, mal selecionado, com grãos dispersos de } \\
\text { areia muito fina a média de quartzo. }\end{array}$ & $\begin{array}{l}\text { Deposição distal no limite } \\
\text { suspensão/tração. Regime } \\
\text { de fluxo inferior. }\end{array}$ \\
\hline
\end{tabular}

Tabela 4. Associação de fácies distal (AFF): fácies, grupos e interpretação dos processos deposicionais.

\begin{tabular}{lccc}
\hline Grupo & Código & Descrição & Interpretação \\
\hline S2F & $\begin{array}{c}\text { Lamito com laminação plano-paralela e boa fissilidade, avermelhado. } \\
\text { Mal selecionado, níveis de areia fina e de mica e impressões de } \\
\text { folhas inteiras (Glossopterídeas). Interdigita-se lateralmente com } \\
\text { arenito grosso a seixoso. }\end{array}$ & $\begin{array}{c}\text { Corrente subaquosa de } \\
\text { tração/suspensão, forma de } \\
\text { leito plana e flotação }\end{array}$ \\
\cline { 2 - 4 } & $\begin{array}{c}\text { Arenito muito fino com laminação plano-paralela, avermelhado, } \\
\text { quartzo-feldspático, com níveis micáceos. Estrutura tipo flama (fl) } \\
\text { na base; intercalação de níveis de arenito fino ou de arenito médio a } \\
\text { grosso; fragmentos carbonosos, Flora Dicroidium (D). }\end{array}$ & $\begin{array}{c}\text { Corrente trativa, fluxo } \\
\text { superior, associada com } \\
\text { plumas de flotação. Forma } \\
\text { de leito plana. }\end{array}$ \\
\hline F & $\begin{array}{c}\text { Siltito avermelhado, com laminação plano-paralela, por vezes, } \\
\text { incipiente (com grãos dispersos de areia média); com níveis de mica. }\end{array}$ & $\begin{array}{c}\text { Corrente de suspensão, } \\
\text { forma de leito plana com } \\
\text { influência de tração e lofting, } \\
\text { na deposiçãa das micas. }\end{array}$ \\
\hline
\end{tabular}


- Subgrupo de fácies F: fácies cujas texturas variam de siltitos a lamitos com laminação plano-paralela, formas de leitos tabulares delgadas ou lençoides, interpretadas como resultantes de plumas de flotação, geradas pela reversão de densidade no processo de lofting (Zavala et al., 2011; Zavala e Arcuri, 2016). Esse fenômeno ocorre pela elevação da água intersticial, menos densa que a da bacia receptora. Esse efeito pode ser resultante do contraste de temperatura entre o fluxo extrabacinal mais quente que adentra em corpo d'água mais frio;

- Fácies S2F: a fácies $\mathrm{S} 2$ relaciona-se vertical e lateralmente à $\mathrm{F}$, gerando uma fácies transicional de ritmitos S2F, caracterizada por uma intercalação milimétrica de arenito fino ou muito fino com lamitos, níveis de mica e/ou fragmentos de plantas. Formação de laminação plano-paralela envolvendo processos de dispersão de fluxos de regime de fluxo superior de canais rasos desconfinantes, em morfologias lençoides, combinados ao processo de plumas de flotação, que pode estar associada a áreas próximas a diques marginais.

\section{Caracterização petrográfica}

Foram selecionadas cinco fácies para estudo de detalhe dos perfis colunares PGAM1308 e PGAM1305, posicionados no setor SW do GAM (Figura 1).

A fácies arenito grosso seixoso com estratificação cruzada tangencial $[\mathrm{Ag} / \mathrm{Sx}(\mathrm{t})]$ (Figura $8 \mathrm{~A}$ ) do perfil colunar PGAM1308, em lâmina petrográfica é um arenito com $38 \%$ de areia grossa e $20 \%$ de areia muito grossa visualmente determinados. Trata-se de um arenito mal selecionado, pois também ocorrem outras granulometrias como areia muito fina, fina, média, além de fração argila (15\%). É grão suportado, porém apresenta uma matriz argilosa e
Fácies: Ag/Sx-Gr(lpp)
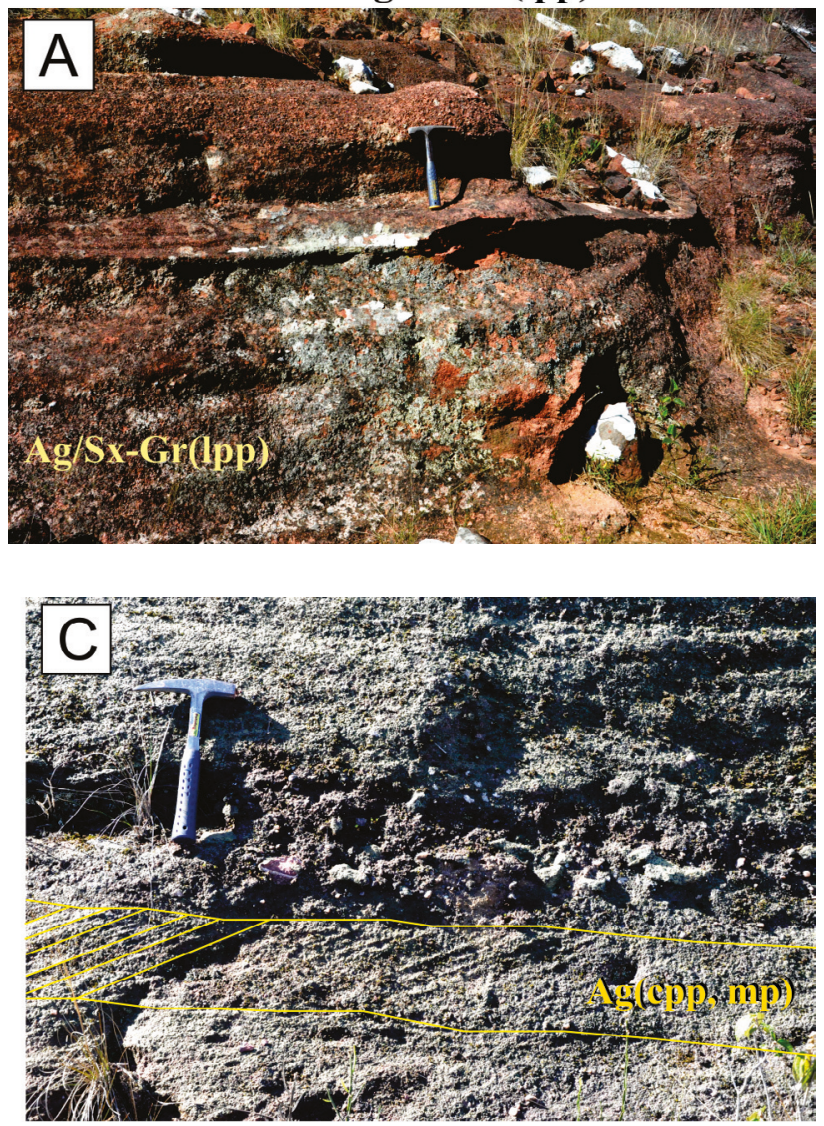

Fácies: $\operatorname{Ag}(\mathbf{c p p}, \mathrm{mp})$

\section{Fácies: $\operatorname{Ag}(t, g p) n S x / G r$}
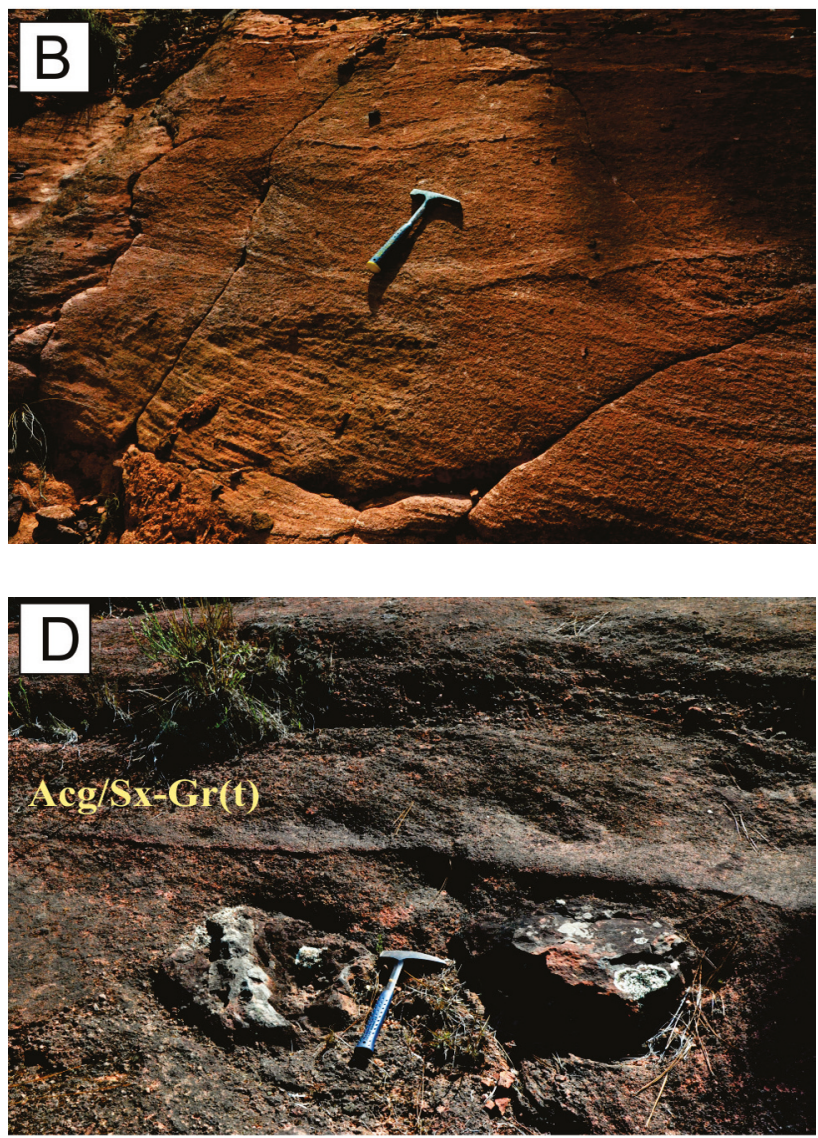

Fácies: $\mathbf{A c g} / \mathbf{S x}-\mathbf{G r}(\mathbf{t})$

Figura 5. Prancha de fotos da associação de fácies proximal de carga de leito (AFL). (A) Ag/Sx-Gr(lpp) - arenito grosso, seixoso a granuloso, com estratificação plano-paralela, (L3); (B) $\mathrm{Ag}(\mathrm{t}) \mathrm{gp}, \mathrm{nSx} / \mathrm{Gr}$ - arenito grosso com estratificação cruzada tangencial de grande porte, com níveis de seixos e grânulos, (L2); (C) Ag(cpp)mp - arenito grosso, com estratificação cruzada plano-paralela de médio porte, (L2); (D) Acg/Sx-Gr(t) - arenito conglomerático seixoso a granuloso, com estratificação cruzada tangencial, (L2). Mais detalhes das descrições vide Tabela 2. 
oxidada, destacando-se o mineral de caulinita. É constituído de $58 \%$ de quartzo policristalino, $33 \%$ de quartzo monocristalino e $8 \%$ de feldspatos e traços de muscovita. É um subarcósio, com porosidade em torno de 7\%, sendo do tipo intergranular, shrinkage, além de microporosidade (Figura 8).

A fácies arenito conglomerático seixoso a granuloso, com estratificação plano-paralela [Acg/Sx-Gr(lpp)] (Figura 9A), do perfil colunar PGAM1308, é um arenito com grânulos subangulosos de intraclastos (25\%), fração predominantemente angulosa com areia muito grossa a grossa $(60 \%)$ e matriz argilosa (15\%). É sustentado pelos grãos e mal selecionado. É um subarcósio estimado visualmente com $61 \%$ de quartzo policristalino, $28 \%$ de quartzo monocristalino e $11 \%$ de feldspatos. A porosidade foi estimada em torno de 7\%, sendo intergranular, shrinkage e microporosidade (Figura 9).

A fácies arenito grosso a seixoso, com laminação plano-paralela $[\mathrm{Ag} / \mathrm{Sx}-\mathrm{Gr}(\mathrm{lpp})]$ (Figura 10A), do perfil colunar PGAM1308 é um arenito com $25 \%$ de grânulos e $25 \%$ de areia muito grossa, também areia muito fina a grossa (20\%) e fração argila (30\%), sustentado pelos grãos. Classificado como subarcósio e constituído de $64 \%$ de quartzo policristalino, $36 \%$ de quartzo monocristalino e traços de mica. A porosidade visual é praticamente nula eventualmente por fraturamento de grãos. A matriz argilosa é em grande parte, recristalizada para caulinitas (Figura 10).

A fácies arenito conglomerático seixoso a granuloso, com estratificação cruzada tangencial [Acg/Sx-Gr(t)] (Figura 11A) do perfil colunar PGAM1305 é um arenito com grânulos de intraclastos (20\%), predominando areia muito grossa a grossa (65\%) e matriz argilosa $(15 \%)$ oxidada e agregados de caulinita. É classificado como subarcósio e constituído de $52 \%$ de quartzo policristalino, $31 \%$ de quartzo monocristalino, $2 \%$ de feldspatos e traços de muscovita. A porosidade foi estimada visualmente em até $7 \%$, intergranular secundária, shrinkage e microporosidade.

\section{Fácies: Af(lpp)}
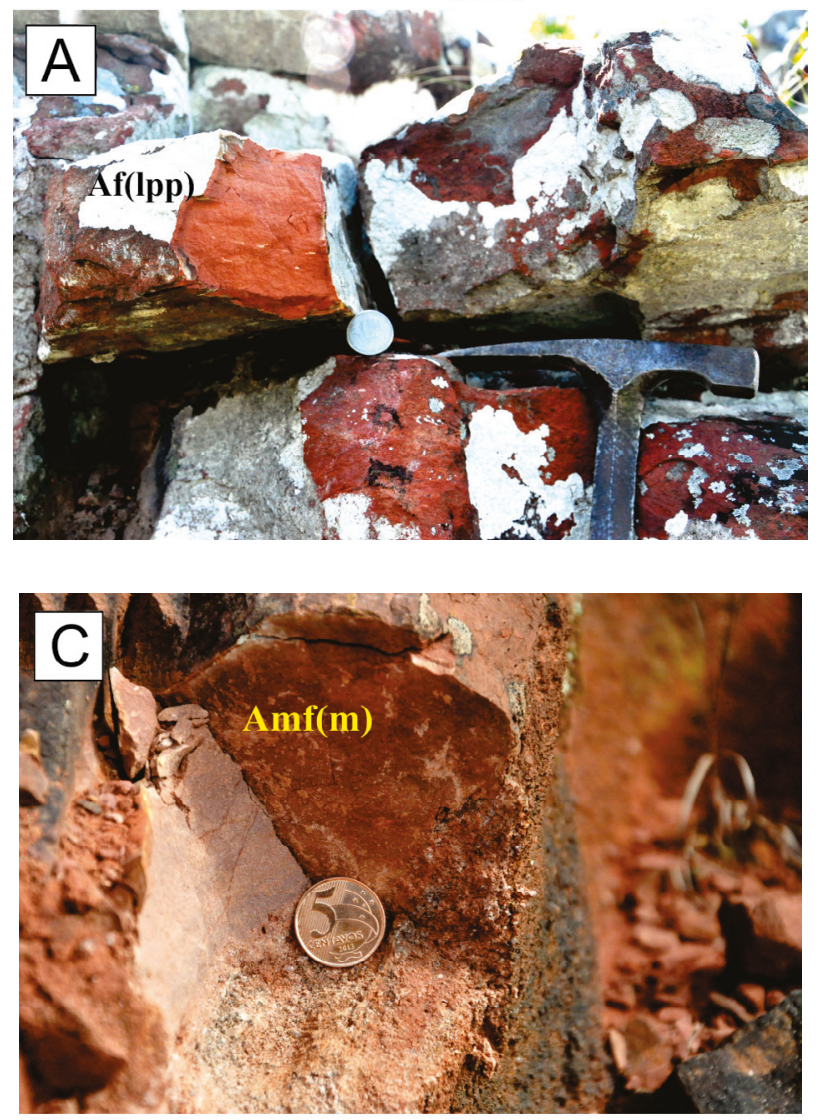

Fácies: $\operatorname{Amf}(\mathrm{m})$
Fácies: $\operatorname{Ag}(\mathrm{m})$
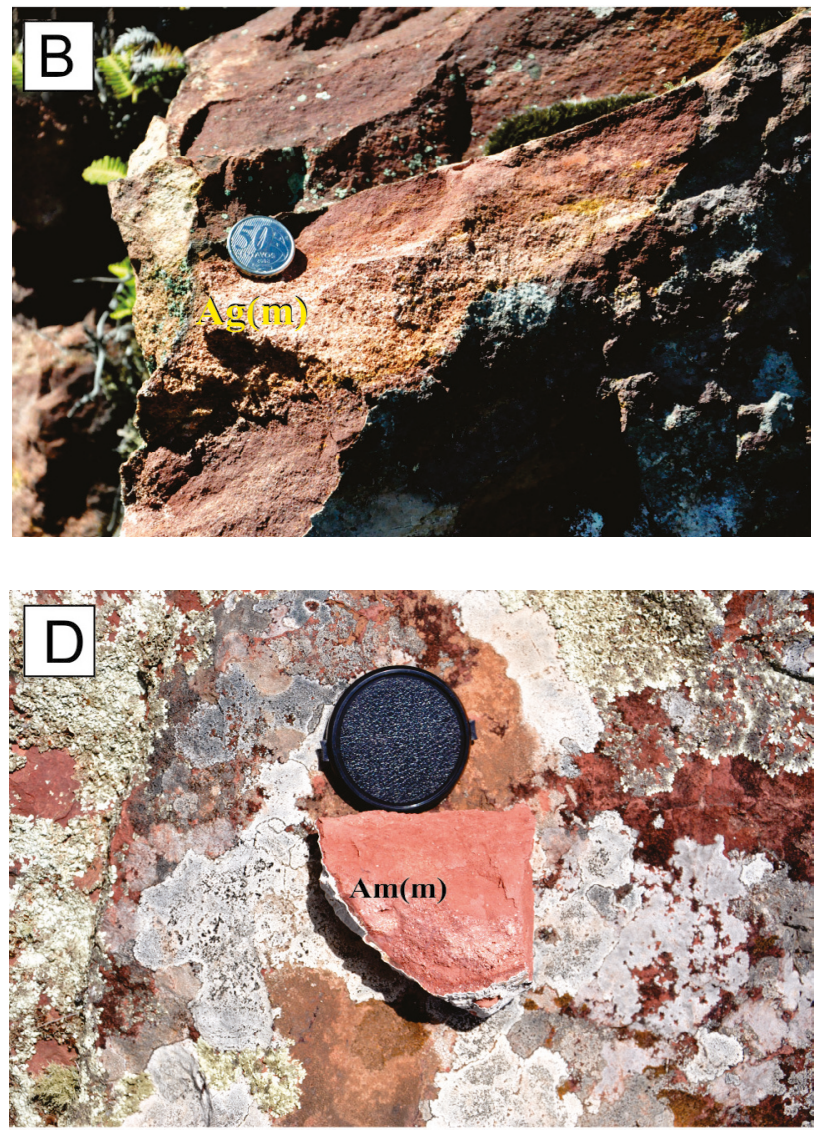

Fácies: Am(m)

Figura 6. Prancha de fotos da Associação de fácies mediana (AFS). (A) Af(lpp) - arenito fino com laminação planoparalela, (S2); (B) $\mathrm{Ag}(\mathrm{m})$ - arenito grosso maciço, (S1); (C) Amf(m) - arenito muito fino maciço, (S1); (D) Am(m) - arenito médio maciço, (S1). Mais detalhes das descrições vide Tabela 3. 
A fácies arenito grosso, com estratificação cruzada tangencial em sets festonados, com níveis de seixos e grânulos [Ag(t)f,nSx/Gr] (Figura 12A) do perfil colunar PGAM130 é um arenito com $22 \%$ de areia média e grânulos ( $3 \%$ ), areia muito grossa $(5 \%)$, areia grossa $(10 \%)$, areia fina $(15 \%)$, areia muito fina (5\%) e pseudomatriz (30\%), pois são agregados de caulinita substituindo grãos. É um subarcósio e constituído por $65 \%$ de quartzo monocristalino, $26 \%$ de quartzo policristalino, $9 \%$ de feldspatos e traços de muscovita. A porosidade foi estimada visualmente em $5 \%$ e pode ser caracterizada como intergranular secundária e microporosidade.

\section{Análise das sucessões de fácies e modelo deposicional}

Para a identificação de sucessões de fácies nos pacotes sedimentares do GAM foi considerada a variação vertical de atributos como: variação textural granodecrescente ascendente, mudança brusca no padrão textural e contatos por superfícies erosivas. Para tanto, fez-se o reconhecimento da variação granulométrica granodescrescente ascendente, bem como a mudança abrupta do tamanho do grão entre o topo da sucessão sotoposta e a base da sobreposta [mudança de St (lpp) para Acg/Sx-Gr]. As sucessões são unidades operacionais que correspondem às unidades sequenciais controladas pelas variações do nível de base.

A integração da distribuição lateral de fácies e da recorrência do padrão cíclico das sucessões de fácies (e suas associações L, S e F) possibilita identificar o modelo deposicional constituído que afere hiperpicnitos. As sucessões de fácies são constituídas, na base, de fácies de texturas mais grossas, a exemplo de conglomerados e arenitos conglomeráticos tipicamente da associação de fácies $\mathrm{L}$

\section{Fácies: Lm(lpp)}
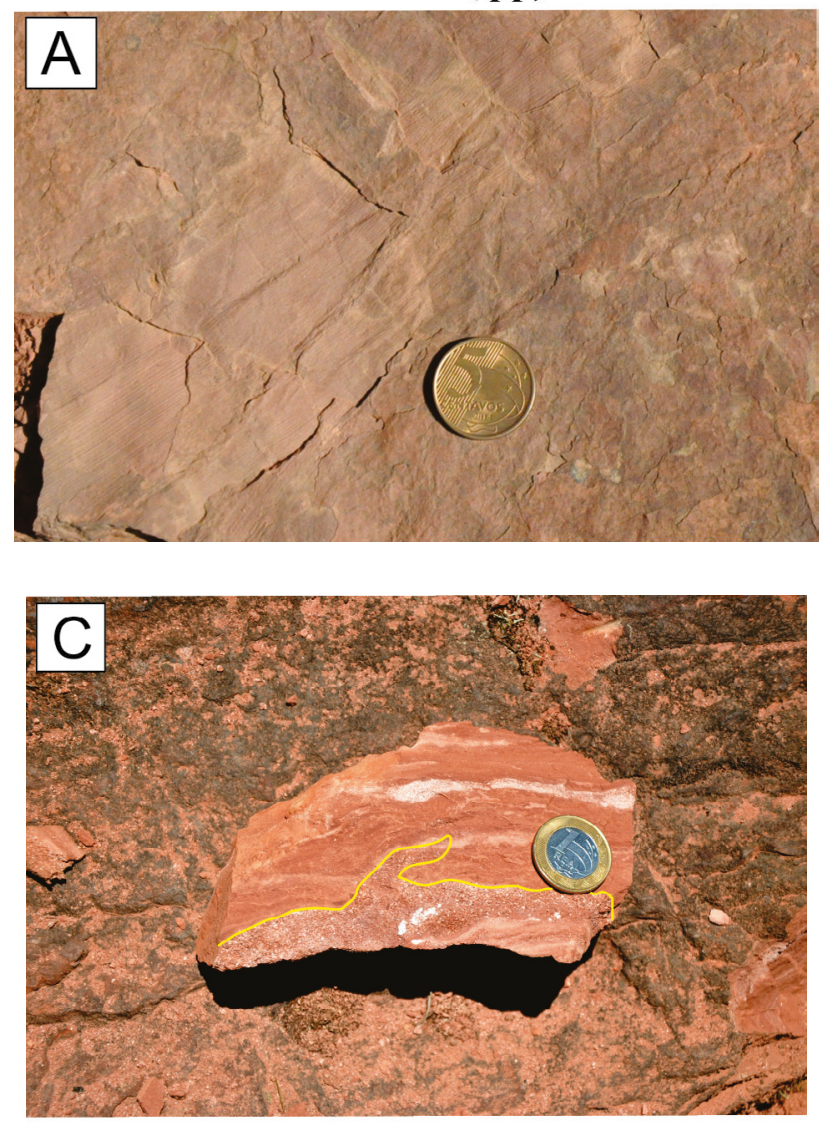

Fácies: Amf(lpp)

\section{Fácies: St(lpp)nmi}
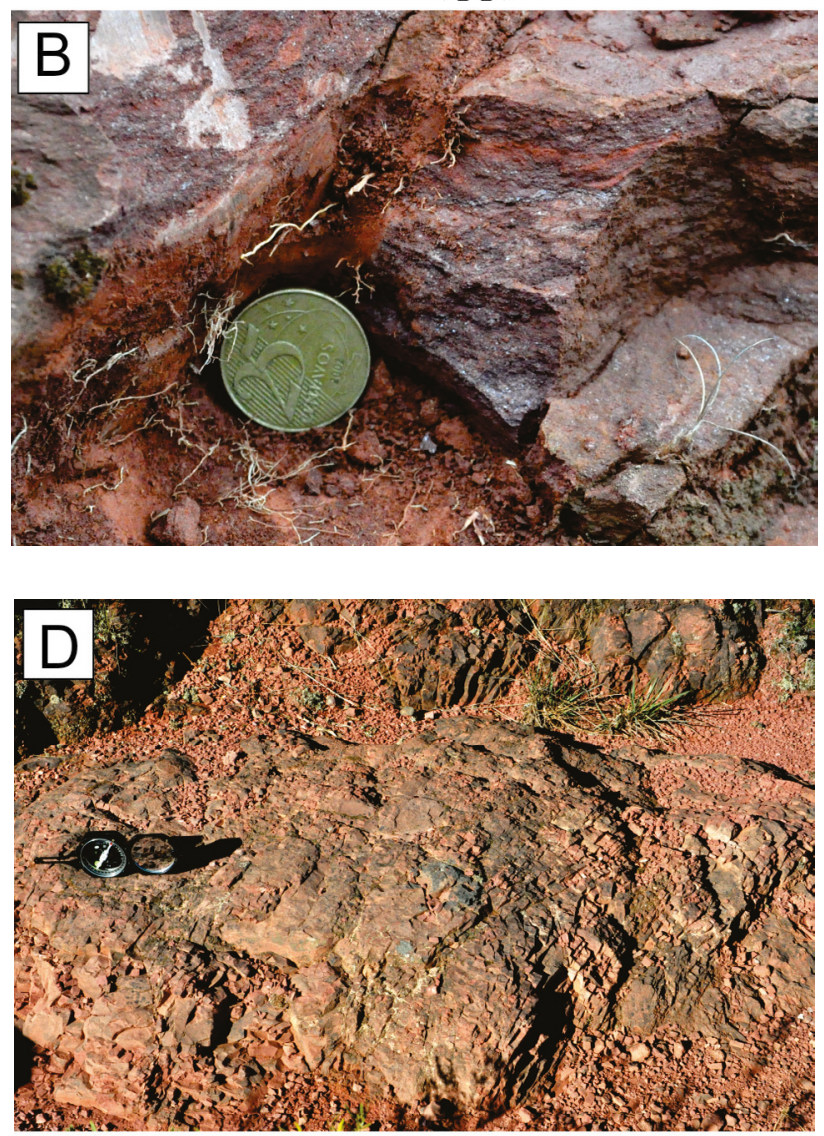

Fácies: $\operatorname{St}(\mathrm{m})$

Figura 7. Prancha de fotos da Associação de fácies Distal (AFF). (A) Lm(lpp) - lamito com laminação plano-paralela, (S2F); (B) St(lpp)nmi - siltito avermelhado, com laminação plano-paralela, com níveis de mica (F); (C) Amf(lpp) - arenito muito fino com laminação plano-paralela, e estrutura de carga, (S2L); (D) St(m) - siltito maciço, avermelhado, mal selecionado, (S4). Mais detalhes das descrições vide Tabela 4. 
(porção proximal), sucedidas por arenitos grossos e médios da associação de fácies S (porção mediana), por sua vez encimadas por fácies de texturas mais finas, como arenito fino a muito fino do subgrupo de associação de fácies S4 (porções mediana e distal). Por fim, fácies de lamitos, siltitos e argilitos da associação de fácies $\mathrm{F}$ (porção distal) capeiam a sucessão (Figura 8). Entre os lamitos, distinguem-se aqueles com níveis significativos de mica (Figura 7B), que resultaram da deposição da pluma de flotação ou lofting (associação de fácies F). Tanto a sucessão de fácies como as associações de fácies permitem identificar o modelo deposicional de hiperpicnito associado a lagos. Destaca-se que as associações de fácies L e S têm características de fácies-reservatório e são capeadas pelas associações de fácies F, eventuais selantes. Assim, os ciclos deposicionais em que as fácies arenosas são expressivas e capeadas por fácies argilosas podem ser considerados como um análogo de reservatório (Figura 13).

\section{Geometria dos depósitos propostos como análogos de reservatório}

A avaliação da geometria, continuidade lateral e vertical das prováveis fácies-reservatório foi realizada por meio de fotomosaicos e análise de campo dos afloramentos dos perfis colunares PGAM1308 (Figura 14) e PGAM1305 (Figura 15), com espessuras, respectivamente, de 17 e $44 \mathrm{~m}$, posicionados no setor SW do GAM (Figura 3).

Na porção mediana do perfil colunar PGAM1308 (Figura 14), identifica-se por [Acg/Sx-Gr(lpp)] a fácies arenito conglomerático seixoso a granuloso com laminação plano-paralela, igualmente observados nos fotomosaicos 1 e 2 . O conjunto de camadas relacionado a essa fácies tem uma boa continuidade lateral (aproximadamente $100 \mathrm{~m}$ ), geometria tabular totaliza $3,5 \mathrm{~m}$ de espessura. $\mathrm{Na}$ porção superior do mesmo perfil e no fotomosaico 3, identifica-se por $[\mathrm{Ag} / \mathrm{Sx}-\mathrm{Gr}(\mathrm{lpp})]$ a fácies de arenito grosso

\section{PGAM1308}
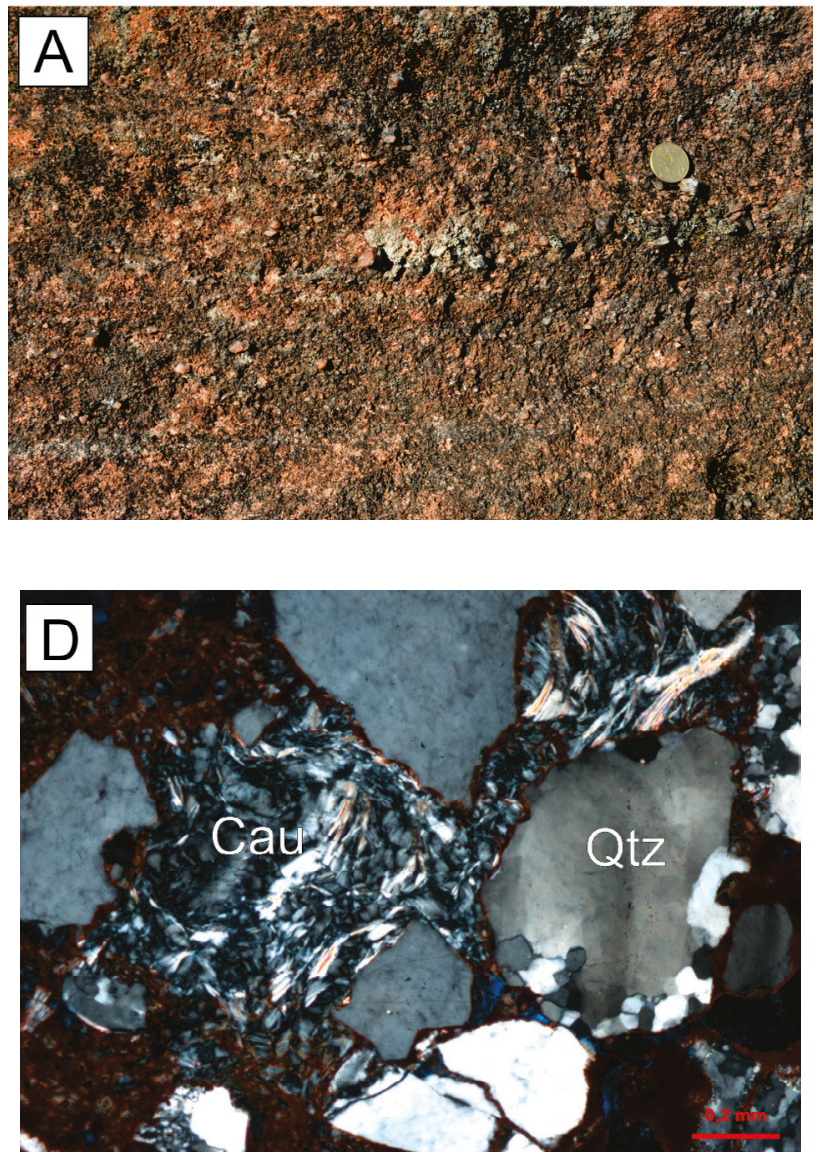

Fácies: $\mathrm{Ag} / \mathrm{Sx}(\mathrm{t})$
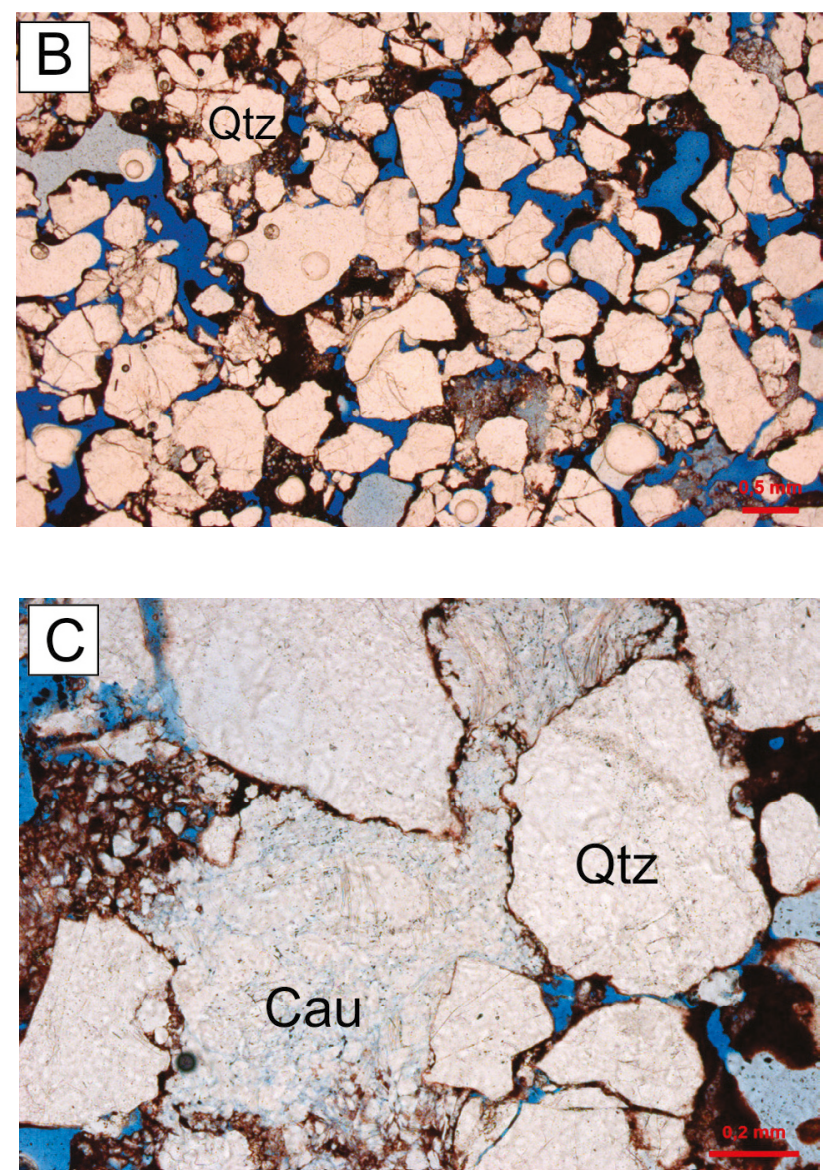

Figura 8. Fotografias e fotomicrografias da fácies arenito grosso a seixoso com estratificação cruzada tangencial [Ag/ Sx(t)]: (A) Aspecto macroscópico da amostra; (B e C) observar a textura da amostra, porosidade intergranular e shinkage em nicóis paralelos; (D) fotomicrografia, em nicóis cruzados destacando-se a caulinita (Cau) e quartzo (QTZ). 
seixoso a granuloso com laminação plano-paralela, com geometria tabular e continuidade lateral de aproximadamente, $50 \mathrm{~m}$, espessura de $2,5 \mathrm{~m}$ e intercalação de uma delgada camada da fácies de arenito grosso maciço. As fácies selantes, como o lamito laminado em cor verde no perfil (Figura 14), são igualmente contínuas e com razoável extensão lateral. Na porção inferior do perfil colunar PGAM1305-A (Figura 15), a fácies arenito muito fino com laminação plano-paralela [Amf(lpp)] de geometria lençoide, com espessura de 3,5 m e intercalação com delgadas camadas da fácies de arenito médio, constitui um ritmito. Há, sobreposta, uma camada de $1,5 \mathrm{~m}$ de espessura, tabular da fácies arenito grosso com estratificação cruzada plana de médio porte $[\mathrm{Ag}(\mathrm{cpp}) \mathrm{mp}]$, que está em contato plano com a camada sobreposta da fácies arenito conglomerático seixoso-granuloso com estratificação cruzada tangencial [Acg/Sx-Gr(t)], esta também com geometria tabular e boa continuidade lateral. Esta última fácies está representada em detalhe no fotomosaico 5
(Figura 15), em que se destacam as superfícies de menor ordem, que limitam cosets, os quais salientam heterogeneidades internas.

\section{Correlação e modelo análogo}

Em cada perfil colunar foram identificadas unidades fundamentais, com base em critérios de delimitação de superfícies erosivas na base e no topo, que podem representar eventos de erosão regional ou de deposição síncrona em toda a área e permitem a identificação de sequências deposicionais correlacionáveis regionalmente. As unidades fundamentais correspondem, assim, por definição, a ciclos deposicionais controlados por variações do nível de base. As superfícies-chave identificadas e que delimitam esses ciclos deposicionais constituem-se como: superfícies erosivas na base das sucessões de fácies e suas conformidades correlativas; superfícies de máxima inundação (SIM) posicionadas no topo dos ciclos, por um conjunto
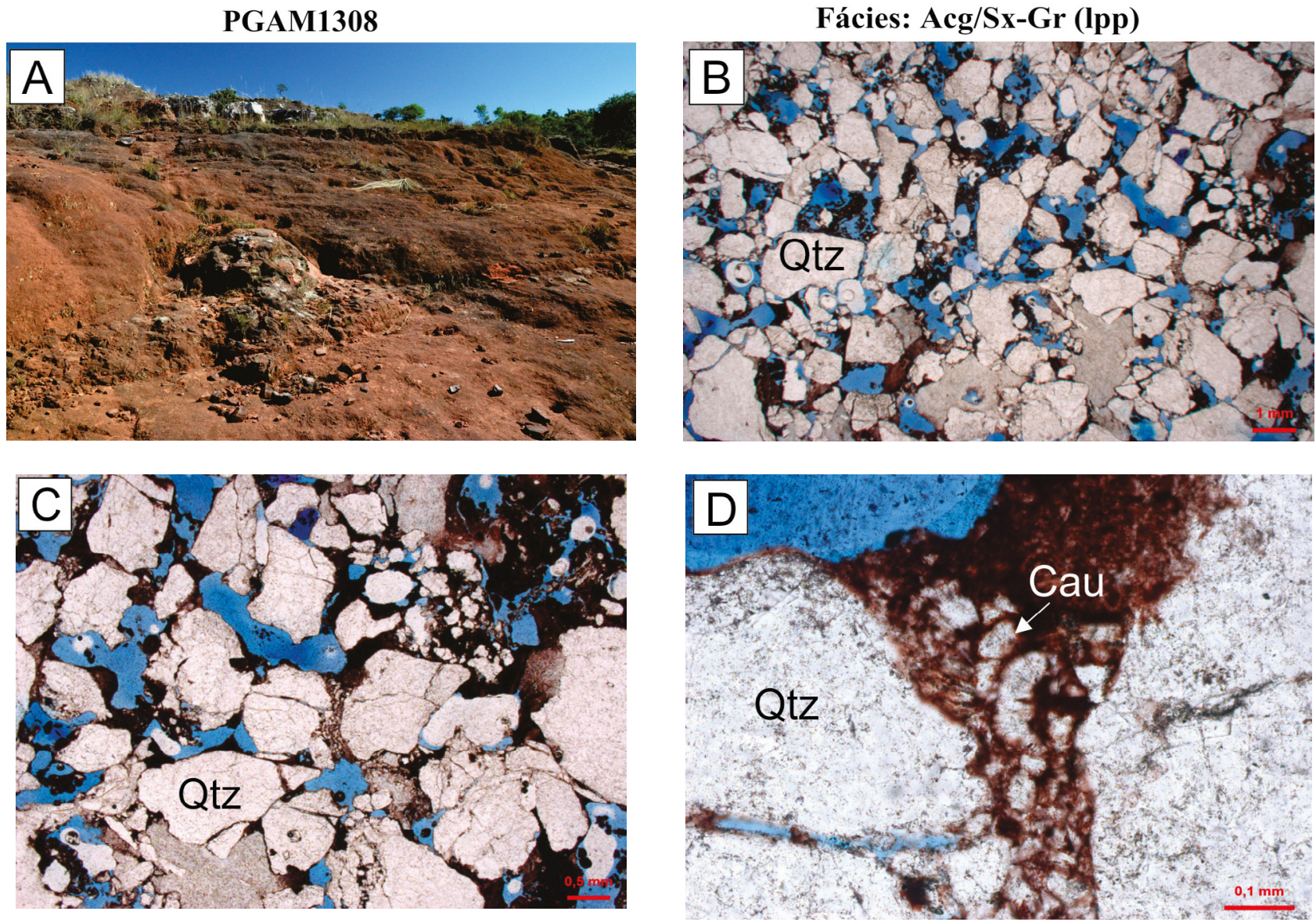

Figura 9. Fotografias e fotomicrografias da fácies arenito conglomerático seixoso a granuloso com estratificação plano-paralela [Acg/Sx-Gr(lpp)]. (A) Afloramento e aspecto macroscópico; (B e C) aspecto geral mostrando grãos mal selecionados, quartzo (QTZ), porosidade (em azul) e traços de matriz argilosa em nicóis paralelos; (D) Detalhe ressaltando a matriz argilosa e agregados de caulinita (Cau) em nicóis cruzados. 
de camadas de fácies finas que caracterizam agradação ou retrogradação máxima. A correlação dos perfis colunares do setor SW do GAM permitiu identificar quatro ciclos deposicionais (CDs) completos e um, no topo, incompleto, com espessuras variando de 3,75 a 12,0 $\mathrm{m}$, cujas heterogeneidades deposicionais são interpretadas como resultantes da desaceleração de fluxos hiperpicnais.

Esses CDs são limitados, na base, por superfícies erosivas que variam lateralmente para superfícies de conformidade correlativa, indicadas por mudanças abruptas de textura (Figura 16). Geralmente, iniciam-se na base com fácies conglomeráticas que são sobrepostas por arenitos grossos a finos e eventualmente, siltitos e lamitos.

A distribuição lateral e vertical desses depósitos cíclicos demonstrada na correlação de quatro perfis colunares (ver PGAM1204, 1308, 1305, 1309 na Seção de Correlação da Figura 16) pode ser também entendida pelo modelo de distribuição lateral de associações de fácies (Figura 17), proposto por Zavala et al. (2011) para fluxos hiperpicnais. Nessa seção, no perfil PGAM1204, bem à esquerda, predomina a associação de fácies da porção proximal (AFL), que corresponde a conglomerados com contatos basais erosivos em zona de by pass. No perfil PGAM1308, predomina a associação de fácies da porção mediana proximal (AFS), identificada por conglomerados, superfícies basais erosivas e fácies de granulometrias finas no topo. No perfil PGAM1305 seguinte, prevalece a associação de fácies da porção mediana distal (AFS), constituída de arenitos grossos a finos, capeados por pelitos. Por fim, no perfil PGAM1309, sobressai a associação de fácies da porção distal (AFF), que corresponde a arenitos muito finos e pacotes mais espessos de pelitos.

Pela distribuição lateral de fácies, é possível identificar o sentido de desaceleração do fluxo hiperpicnal e a conformação de depósitos areno-conglomeráticos, possíveis reservatórios, capeados por pelitos (em verde) (Figura 17).
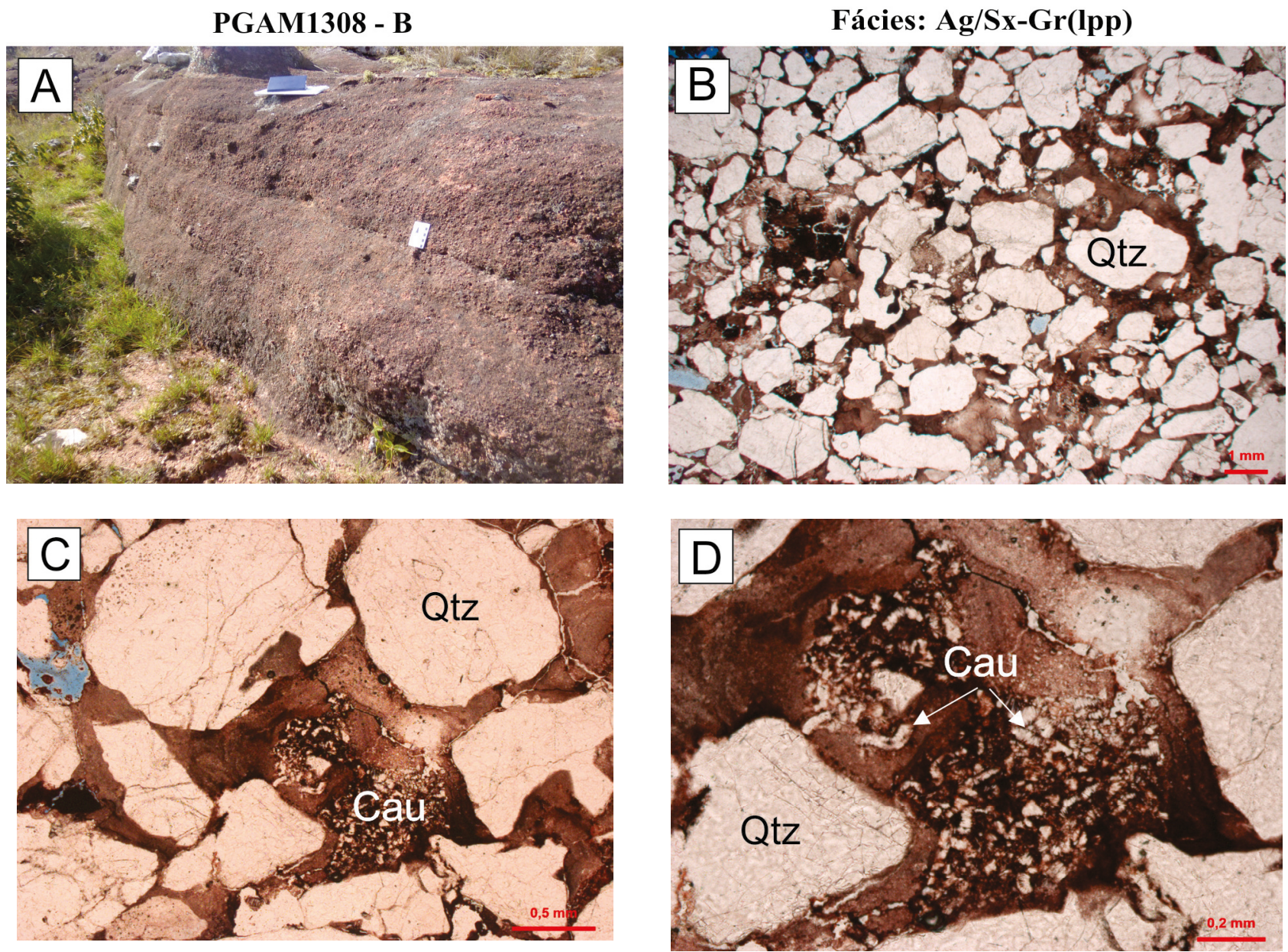

Cau: caulinita; Qtz: quartzo.

Figura 10. Fotografias e fotomicrografias da fácies arenito grosso seixoso a granuloso com estratificação plano-paralela [Ag/Sx-Gr(lpp)]. (A) Aspecto de campo; (B, C e D) Fotomicrografias em ND. 


\section{Análogo de reservatório}

Considerando o modelo, foi feita uma análise multiescalar (Paim et al., 2003) para entender a potencialidade desses depósitos como um análogo de reservatório. Nesse modelo, pode-se compreender que a associação de fácies L (AFL), relacionada à carga de leito, representa o início de cada ciclo deposicional. Essa associação de fácies, quando ocorre em ciclos com grande representatividade em espessos pacotes, constitui-se em um potencial análogo de reservatório. Em microescala, foi possível constatar, por meio de análises petrográficas, especificamente para as fácies da AFL, quais sejam, [Ag/Sx(t)], [Acg/Sx-Gr(lpp)] e [Acg/Sx-Gr(t)], a baixa porosidade (no máximo 7\%), do tipo intergranular secundária, intergranular por fraturas e microporosidade em caulinitas, assim como foi diagnosticada a cimentação e substituição de feldspatos por caulinita. A única fácies com porosidade praticamente nula foi a $[\mathrm{Ag} / \mathrm{Sx}-\mathrm{Gr}(\mathrm{lpp})]$, isso se deve ao padrão de alta carga de lama que preenche boa parte dos poros, também evidenciado pelos dados petrográficos de rochas aflorantes desse modelo de hiperpicnito lacustre.

Essas fácies analisadas em lâmina petrográfica puderam ser entendidas em mesoescala, por meio dos fotomosaicos, gerados em dois perfis detalhados referentes às Figuras $14 \mathrm{e}$ 15. A análise desses fotomosaicos possibilitou o entendimento das heterogeneidades presentes no depósito por parâmetros como geometria, relações de contato e estruturas internas das camadas. A geometria das fácies aqui analisadas é predominantemente tabular ou lençoide, resultante do registro de canais rasos e pouco escavados. As geoformas são compatíveis com as geometrias geradas por fluxos hiperpicnais,

\section{PGAM1305 - A}
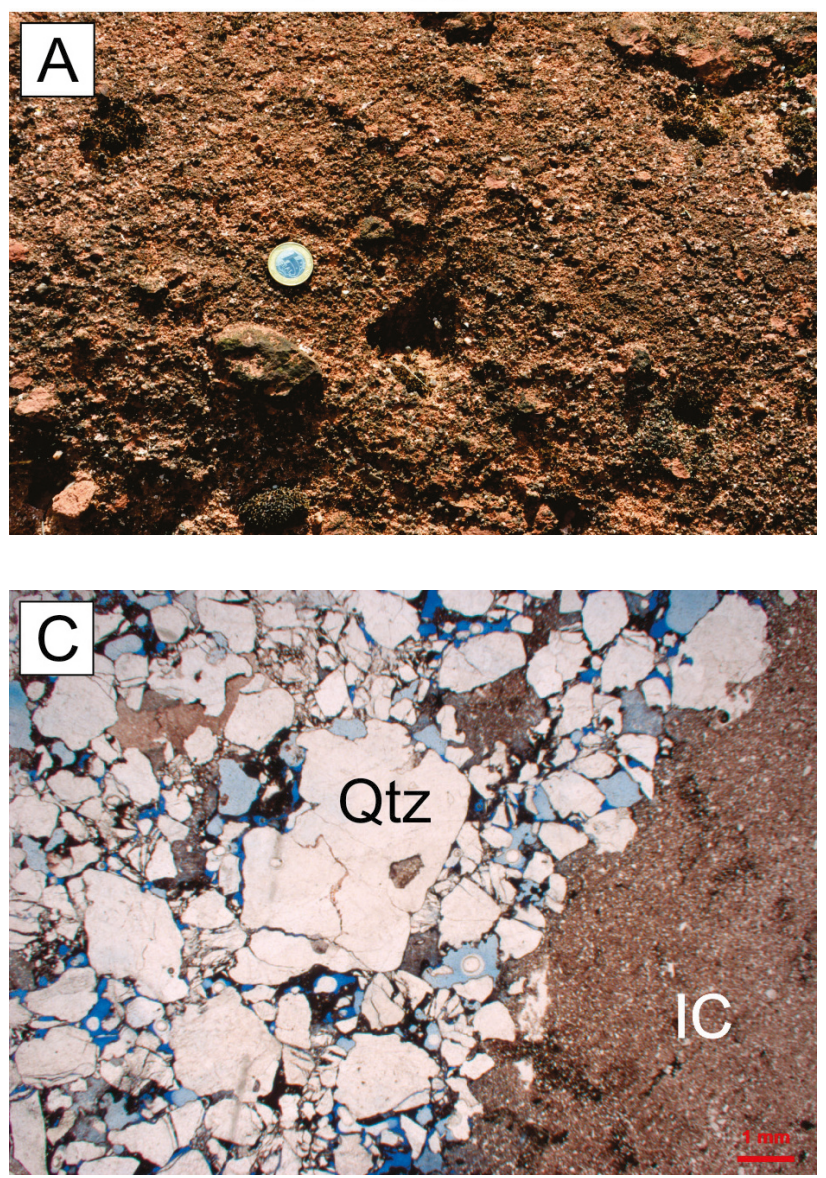

Fácies: Acg/Sx-Gr(t)
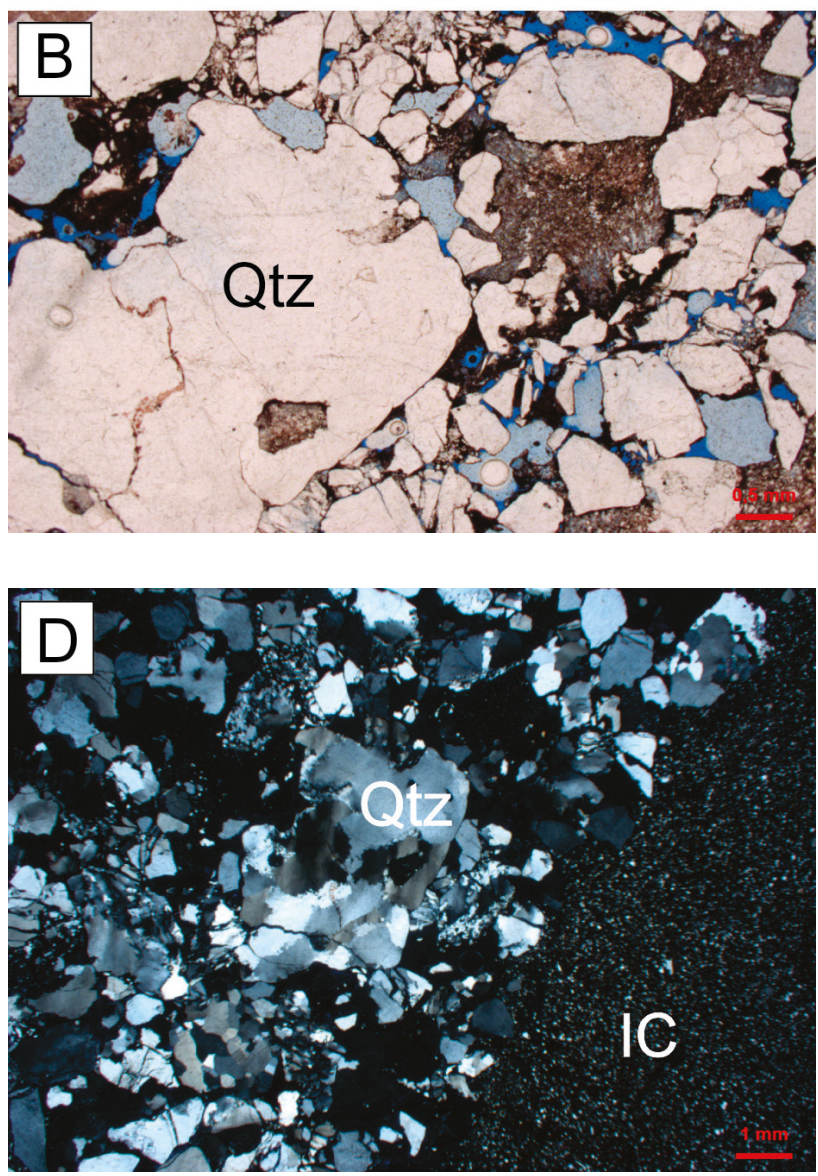

Figura 11. Fotografias e fotomicrografias da fácies arenito conglomerático seixoso a granuloso com estratificação tangencial [Acg/Sx-Gr(t)]. (A) Afloramento e aspecto macroscópico; (B e C) detalhe mostrando arcabouço, grãos de quartzo (QTZ) e intraclasto (IC) em nicóis paralelos; (D) detalhe da fotomicrografia em C, com nicóis cruzados salientando o quartzo e intraclasto. 
em que ocorre o espalhamento do fluxo e o desconfinamento de canais (Zavala et al., 2011). Essas relações conferem boa conectividade lateral contínua e de grande extensão das camadas, para um potencial reservatório, como o exemplo de um ciclo, representado por espessas camadas areno-conglomeráticas do perfil 1308 (Figura 14). Este conjunto de camadas está capeado por uma camada de lamito de $1,5 \mathrm{~m}$ com laminação plano-paralela e grande quantidade de mica que resulta da deposição de plumas de flotação ou lofting (associação de fácies F), o que representa o encerramento de um espesso ciclo deposicional correspondendo a fácies selantes, que funcionariam como uma barreira horizontal para fluxos ascendentes no contexto de um reservatório. A recorrência do padrão cíclico retrogradacional de fácies no empilhamento vertical confere heterogeneidade e distribuição de fácies de hiperpicnitos lacustres (Zavala et al., 2011), condição que, em uma análise de macroescala, resultaria em um reservatório compartimentado (Figuras 8, 14 e 15). Com a correlação dos perfis levantados na região, que abrangem uma extensão de aproximadamente $7 \mathrm{~km}$, chega-se a um modelo análogo de reservatório para os depósitos episódicos da porção SW do GAM (Figura 16). Esse modelo tem padrão semelhante quando comparado a estudos de Lira (2004), para análogos de Inunditos, em que também foram demonstradas baixa porosidade e grande lateralidade dos depósitos daquela região. Essa característica é evidenciada, aqui, pela correlação dos perfis colunares e suportado pelo modelo de distribuição de fácies.

\section{DISCUSSÃO E CONCLUSÕES}

Neste artigo, fez-se uma análise de inúmeros modelos deposicionais provenientes de inundações, os Inunditos,
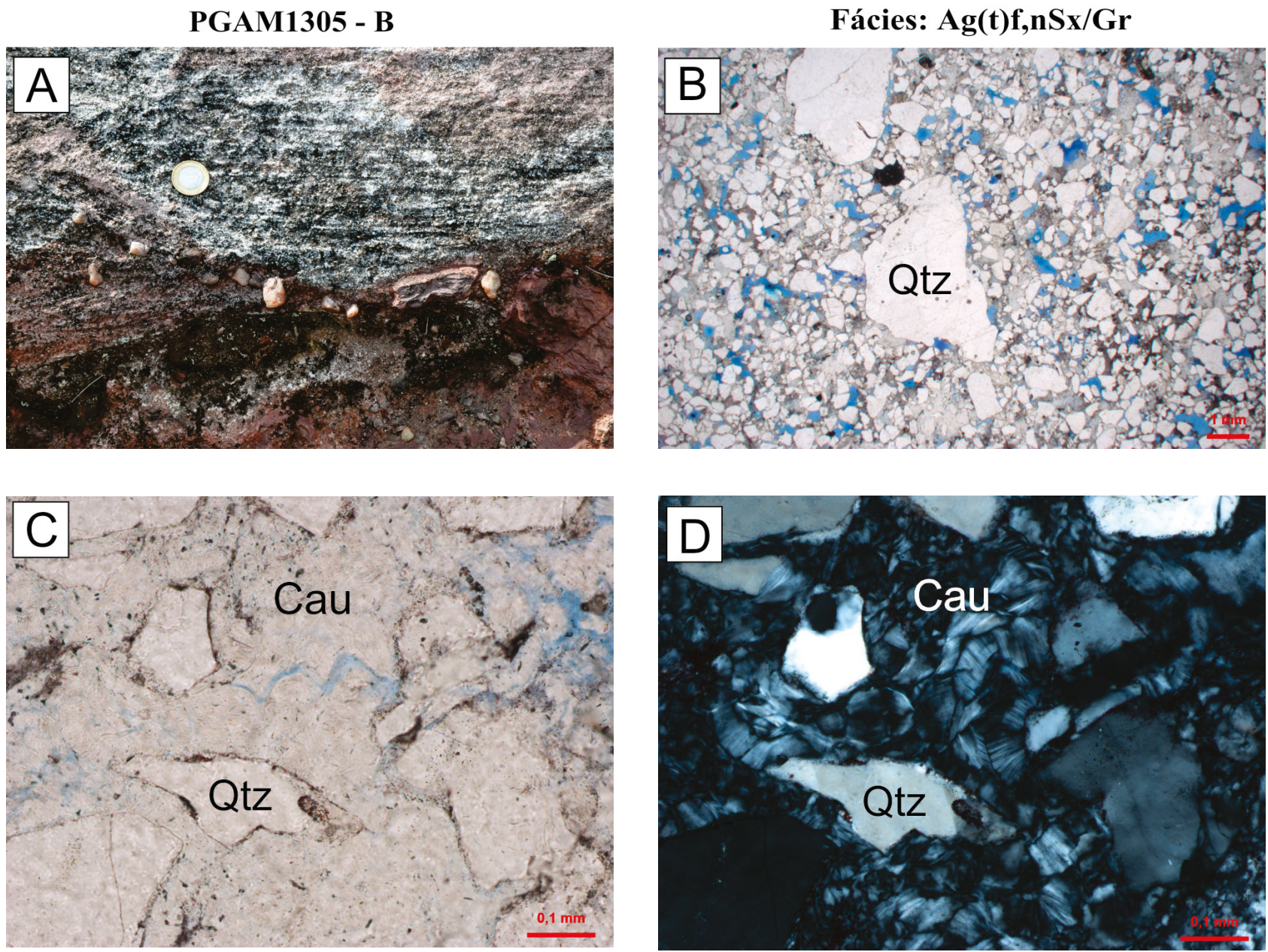

Figura 12. Fotografias e fotomicrografias da fácies arenito grosso, com estratificação cruzada tangencial em sets festonados, com níveis de seixos e grânulos [Ag(t)f,nSx/Gr]. (A) Afloramento e aspecto macroscópico; (B e C) arcabouço com grãos de quartzo (QTZ) e matriz substituída por caulinita (Cau) em nicóis paralelos; (D) detalhe da fomicrografia em C, porém em nicóis cruzados. 


\begin{tabular}{|l|c|c|}
\hline $\begin{array}{l}\text { Sucessão de Fácies } \\
\text { típica de inunditos }\end{array}$ & $\begin{array}{c}\text { Subgrupo } \\
\text { de fácies }\end{array}$ & Fácies \\
\hline & $\mathrm{F}$ & $\mathrm{St}(\mathrm{I})$ \\
\cline { 2 - 3 } & $\mathrm{S} 2$ & $\mathrm{Amf}(\mathrm{lpp})$ \\
\cline { 2 - 3 } & $\mathrm{Af}(\mathrm{bxa})$ \\
\cline { 2 - 3 } & $\mathrm{L} 3$ & $\mathrm{Am}(\mathrm{lpp})$ \\
\hline & $\mathrm{L} 2$ & $\mathrm{Ag}(\mathrm{t})$ \\
\hline & & $\mathrm{Cg} / \mathrm{Sx}(\mathrm{m})$ \\
\hline
\end{tabular}

Figura 13. Perfil de uma sucessão de fácies característica de um Inundito do GAM, análoga para reservatório de hidrocarboneto. À esquerda o código dos subgrupos de fácies e, à direita, código de fácies. Modificado de: (A) sucessão de fácies: Lima (2014). (B) subgrupos de fácies: Zavala et al. (2011).

para uma classificação e identificação do modelo para o pacote sedimentar do GAM mais bem suportado por dados de campo. Os dados levantados confirmam o modelo de hiperpicnito de lago, cuja gênese relaciona-se a inundações fluviais que resultam em fluxos hiperpicnais quando adentram os lagos (Tabela 1). As fácies com intraclastos argilosos foram geradas em períodos de recarga d'água, a partir de influxos episódicos que erodiam pavimentos lamíticos, demonstrando que havia grande variação do nível d'água em lagos e que, hoje, são amplamente encontradas no registro na área do GAM. Outra característica que corrobora o modelo de hiperpicnito é a abundância de fácies com fragmentos vegetais e charcoal que foram remobilizados, além de níveis micáceos, indicando o mecanismo deposicional de lofting por decantação de plumas de flotação (Zavala e Arcuri, 2016).

Diferentemente do que ocorre em turbiditos clássicos (Bouma, 1962), os hiperpicnitos (ou turbiditos extrabacinais) não têm a característica de retrabalhamento (revolvimento) nos sedimentos de carga de fundo, mantendo, dessa forma, alta carga de sedimentos finos como matriz e a fraca seleção de grãos, o que pode conferir baixas porosidades em reservatórios desse modelo deposicional (Santos, 2005; Yang et al., 2017; Pestilho et al., 2018). Pela mesma razão, os turbiditos extrabacinais ou hiperpicnitos se distinguem de depósitos fluviais subaéreos pela grande quantidade de matriz em suas fácies. As inundações episódicas geradoras desses depósitos da Sequência Santa Maria II do GAM ocorreram em clima árido e deram origem a fluxos que lavavam a superfície continental, propiciando a alta concentração de sedimentos finos e a elevada densidade (Kelly e Olsen, 1993) que reabasteceriam lagos perenes, sob a forma de fluxos hiperpicnais. Nesse sentido, novos estudos (Cardoso et al., 2018) em rochas do GAM apontam que o espaçamento irregular de anéis de crescimento identificados em charcoal sugerem condições cíclicas de disponibilidade hídrica em clima árido em período de greenhouse. A presença de fósseis de rincossauros (Horn et al., 2015) também aponta para a existência de cursos d'agua duradouros na região. O reabastecimento cíclico de água em paleoclima árido confere um suporte à hipótese de lagos perenes, embora Lima (2016), Borsa et al. (2017) e Lima et al. (2018) tenham proposto modelos de lagos efêmeros para a área. Nesse sentido, não houve evidências de ampla ocorrência de paleossolos que pudessem sustentar a proposição de modelos desenvolvidos em leito seco.

Propõe-se, com base em amplo estudo e análise de fácies do pacote sedimentar do GAM, correlação de perfis colunares, e marcos teóricos de modelos de Inunditos propostos na literatura, um modelo análogo de reservatório do tipo compartimentado, de forma que seus pacotes arenosos são constituídos por geometria tabular, boa extensionalidade, porosidade de no máximo 7\% (em AFL), e rochas selantes de espessura delgada como os lamitos da associação de fácies distal. Com a integração dos dados, demonstra-se que o modelo de depósito de inundação de hiperpicnitos lacustres seria o mais adequado para a área do GAM, relicto Triássico da Bacia do Paraná no Escudo Sul-Rio-Grandense.

\section{AGRADECIMENTOS}

A primeira autora agradece a Coordenação de Aperfeiçoamento de Pessoal de Nível Superior (CAPES), a bolsa de mestrado, e ao Programa de Pós-Graduação em Geociências da Universidade Federal do Rio Grande do Sul, a oportunidade de realização deste trabalho. Agradecemos, ainda, os revisores anônimos desse artigo, que contribuíram sobremaneira para sua melhoria. 

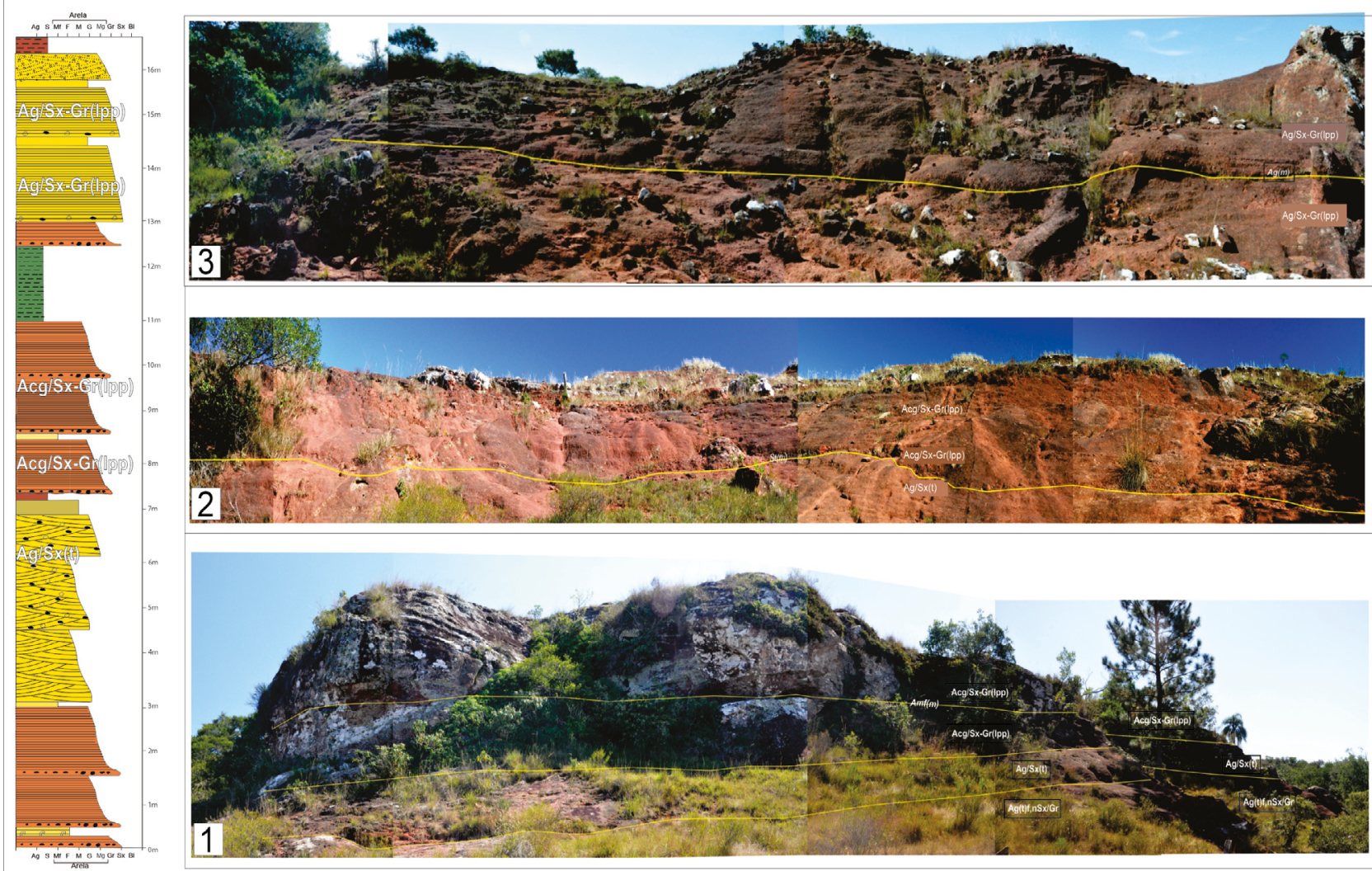

Figura 14. Fotomosaicos 1, 2 e 3 correspondentes ao perfil colunar PGAM1308, nos quais foram marcadas as principais superfícies. Observar que não há truncamento de superfícies nem incisão das mesmas, conferindo boa conectividade lateral em mesoescala para o análogo de reservatório.

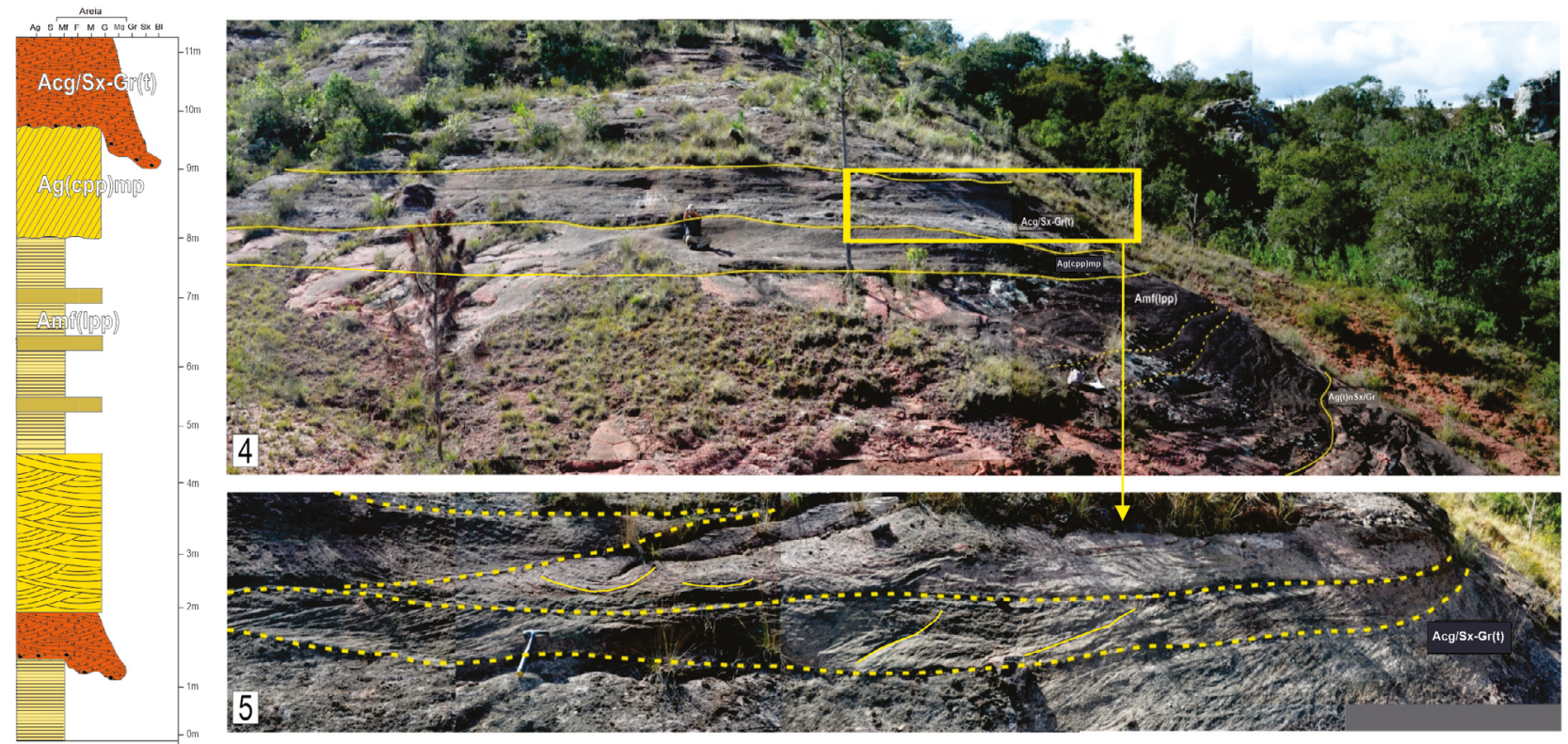

Figura 15. Fotomosaicos 4 e 5 correspondentes ao perfil colunar PGAM1305-A, nos quais foram marcadas as principais superfícies. As linhas contínuas representam contatos de fácies tabulares e, as linhas pontilhadas, representam superfícies de menor ordem, provavelmente reativação da estratificação cruzada acanalada evidenciando as heterogeneidades internas das camadas (fotomosaico 5). 
Seção de correlação de perfis colunares do setor SW do Gráben Arroio Moirão

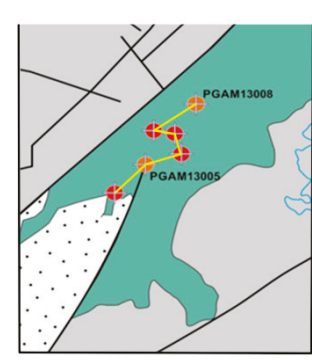

TPaM1306

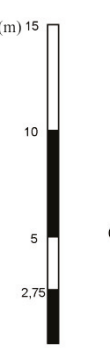

CDI
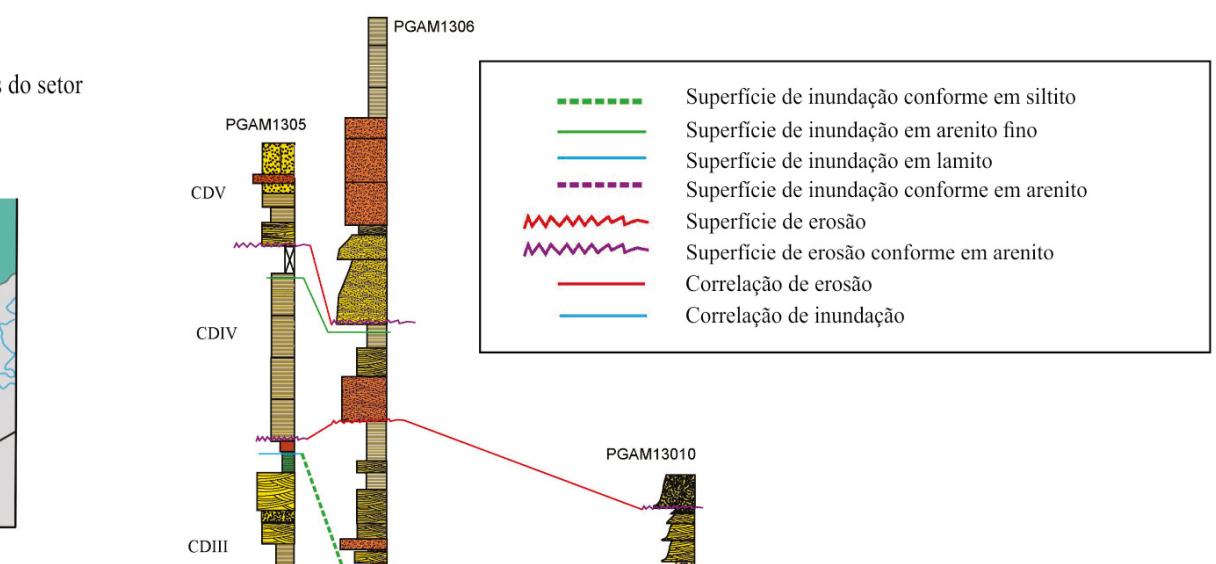

基
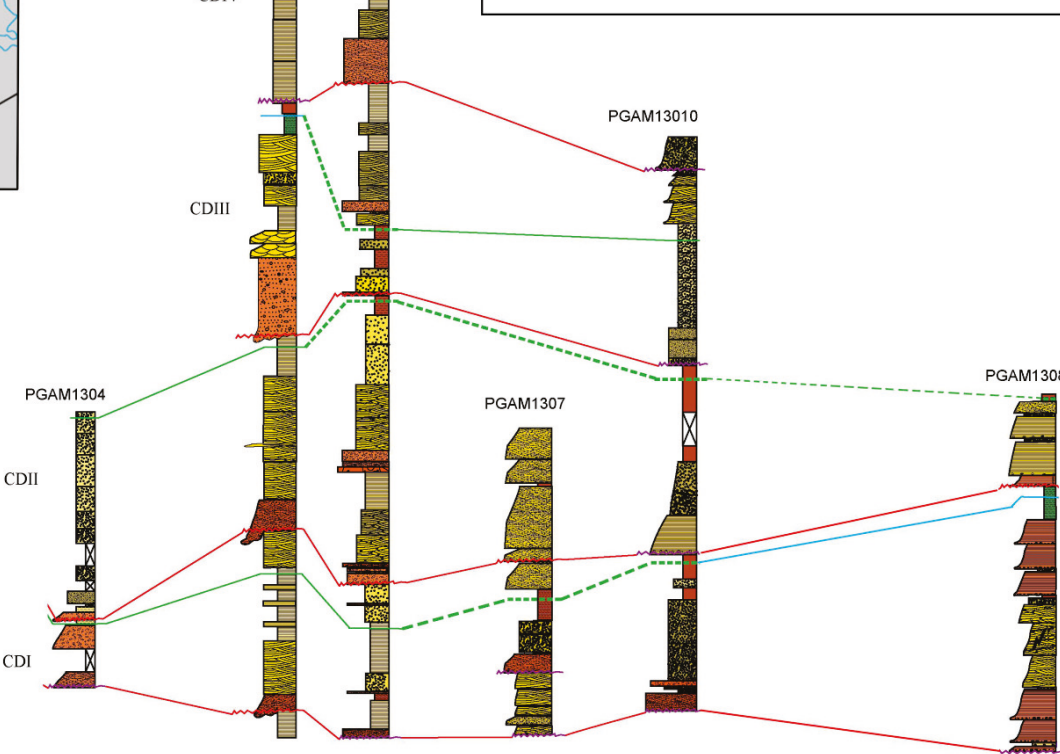

Figura 16. Seção de correlação de perfis colunares do setor SW do GAM e ciclos deposicionais (CDI, CDII, CDIII, CDIV, CDV).

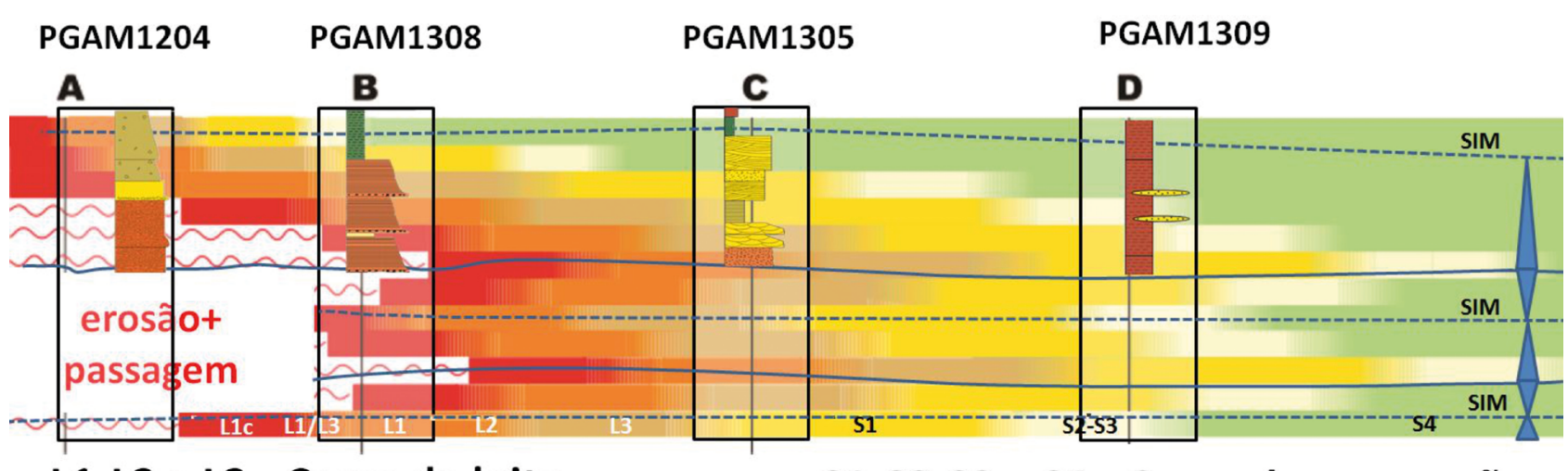

\section{L1-L2 e L3 - Carga de leito}

\section{S1-S2-S3 e S4 - Carga de suspensão}

\section{Corpos canalizados}

\section{Corpos tabulares}

Fonte: modificado de Zavala et al. (2011)

Figura 17. Modelo da distribuição lateral e heterogeneidade de fácies. Os retângulos identificam o posicionamento dos perfis colunares do GAM conforme o modelo de associação de fácies para fluxos hiperpicnais. 


\section{REFERÊNCIAS}

Andreis, R., Bossi, G., Montardo, D. (1980). O Grupo Rosário do Sul (Triássico) no Rio Grande do Sul. XXXI Congresso Brasileiro de Geologia, 2, 659-673. Camboriú: SBG.

Barberena, M. C., Araújo, D. C., Lavina, E. L., Faccini, U. F. (1991). The evidence for close paleo-faunistic affinity between South America and Africa, as indicated by Late Permian and Triassic tetrapods. VII International Gondwana Symposium, 455-467. São Paulo.

Borsa, G. N. O. (2015). Novas chaves de correlação para as unidades triássicas do gráben arroio moirão: caracterização de sismitos e aplicação na estratigrafia. Dissertação (Mestrado). Porto Alegre: Instituto de Geociências - UFRGS.

Borsa, G. N. O., Mizusaki, A. M. P., Menegat, R. (2017). The Triassic belt preserved in Arroio Moirão Graben, southernmost Brazil: Depositional system, sequence stratigraphy and tectonics. Journal of South American Earth Sciences, 77, 123-140. https://doi.org/10.1016/j.jsames.2017.05.002

Bortoluzzi, C. A. (1974). Contribuição à geologia da região de Santa Maria, Rio Grande do Sul, Brasil. Pesquisas em Geociências, 4(4), 7-86. https://doi. org/10.22456/1807-9806.21834

Bouma, A. H. (1962). Sedimentology of some flysch deposits, a graphic approach to facies interpretation. Nova York: Elsevier.

Cardoso, D. S., Mizusaki, A. M. P., Guerra-Sommer, M., Menegat, R., Barili, R., Jasper A., Uhl D. (2018). Wildfires in the Triassic of Gondwana Paraná Basin. Journal of South American Earth Sciences, 82, 193-206. https://doi. org/10.1016/j.jsames.2017.12.018

Catuneanu, O. (2006). Principles of Sequence Stratigraphy. Nova York: Elsevier. https://doi.org/10.1017/ S0016756807003627

Coe, A. L. (2010). Geological field techniques. Milton Keynes: Wiley-Blackwell.

Dalrymple, R. W. (2010). Interpreting Sedimentary Successions: facies, facies analysis and facies models. In: N. P. James, R. W. Dalrymple (Eds.), Facies Models 4. Canadá: Geological Association of Canada.

Della Fávera, J. C. (2001). Fundamentos de Estratigrafia Moderna. Rio de Janeiro: Editora UERJ.

Einsele, G. (2000). Sedimentary basins. Berlim: Springer-Verlag.
Faccini, U. F. (1989). Sequence stratigraphy applied to continental deposits from outcrop analysis: progress and limitations. A case study from Upper Permian-Mesozoic record of the SE edge of Paraná Basin. III Simpósio sobre Cronoestratigrafia da Bacia do Paraná. Boletim de Resumos Expandidos. Barra do Garças-MT: PSBG-RJ.

Faccini, U. F. (2000). Estratigrafia do Permo-Triássico do Rio Grande do Sul: estilos deposicionais versus espaço de acomodação. Tese (Doutorado). Porto Alegre: Instituto de Geociências - UFRGS.

Faccini, U. F., Schultz, C. L., Figueiredo, C. E., Sangineto, L. R., Soares, S. C. (1990). Sobre a ocorrência de vertebrados fósseis triássicos na região de Santana da Boa Vista (RS). Ciência e Natura, 12(12), 103-104. https://doi. org/10.5902/2179460X26256

Fischer, J. A., Krapf, C. B. E., Lang, S. C., Nichols, G. J., Payenberg, T. H. D. (2008). Sedimentology and arquitecture of the Douglas Creek terminal splay, lake eyre, central Australia. Sedimentology, 55(6), 1915-1930. https://doi. org/10.1111/j.1365-3091.2008.00974.x

Folk, R. L. (1968). Petrology of sedimentary rocks. Austin: Hemphill's Publishing Company.

Gamermann, N. (1973). Formação Rosário do Sul. Pesquisas em Geociências, 2(2), 5-36. https://doi. org/10.22456/1807-9806.21859

Gordon, M. (1947). Classification of the Gondwanic Rocks of Paraná, Santa Catarina and Rio Grande do Sul. Boletim do Departamento Geológico e Mineralógico do Brasil, 38, 1-19.

Heward, A. P. (1978). Alluvial fan sequence and megasequence models: With examples from Westphalian D - Stephanian B Coalfields, Northern Spain. In: A. D. Miall (Ed.), Fluvial Sedimentology, p. 669-702. Canadian Society of Petroleum Geologists (Memoir 5). https://doi.org/10.1017/ S0016756800044101

Horn, B. L. D. (2016). Análise sedimentológica da Supersequência Santa Maria e suas implicações estratigráficas. Tese (Doutorado). Porto Alegre: Instituto de Geociências - UFRGS. 99 p.

Horn, B. L. D., Goldberg, K., Schultz, C. L. (2018). Interpretation of massive sandstones in ephemeral fluvial settings: A case study from the Upper Candelaria Sequence (Upper Triassic, Parana Basin, Brazil). Journal of South 
American Earth Sciences, 81, 108-121. https://doi. org/10.1016/j.jsames.2017.10.009

Horn, B. L. D., Melo, T. P., Schultz, C. L., Philipp, R. P., Kloss, H. P., Goldberg, K. (2014). A new third-order sequence stratigraphic frame work applied to the Triassic of the Paraná Basin, Rio Grande do Sul, Brazil, based on structural, stratigraphic and paleontological data. Journal of South American Earth Sciences, 55, 123-132. https://doi. org/10.1016/j.jsames.2014.07.007

Horn, B. L. D., Schultz, C. L., Figueiredo, A. E. Q., Motta, F. A. (2015). Recognition of the hyperodapedon assemblage zone (Late Triassic) in a relictual occurrence over the SulRio-Grandense shield. Revista Brasileira de Paleontologia, 18(1), 91-96. http://dx.doi.org/10.4072/rbp.2015.1.06

James, N. P., Dalrymple, R. W. (Eds.). (2010). Facies Models 4. Newfoundland: Geological Association of Canada.

Kelly, S. B., Olsen, H. O. (1993). Terminal fans - a review with reference to Devonian examples. Sedimentary Geology, 85(14), 339-374. https://doi.org/10.1016/0037-0738(93)90092-J

Leeder, M. (1999). Sedimentology and Sedimentary Basins from Turbulence to Tectonics. Oxford: Blackwell Science. https://doi.org/10.1017/S0016756800224618

Lima, L. G. (2014). Análise de fácies e modelos deposicionais de unidades triássicas da Bacia do Paraná sobre o Escudo Sul-Rio-Grandense na região do Gráben Arroio Moirão, RS: Em busca de marcadores estratigráficos. Monografia (Graduação). Porto Alegre: Instituto de Geociências-UFRGS.

Lima, L. G. (2016). Inunditos como um modelo sedimentar - identificação no Gráben Arroio Moirão (RS). Dissertação (Mestrado). Porto Alegre: Instituto de Geociências-UFRGS.

Lima, L. G., Menegat, R., Mizusaki, A. M. M. (2018). Inunditos como modelo deposicional no Triássico da Bacia do Paraná: um exemplo no gráben Arroio Moirão (RS). Revista Geociências, 37(1), 3-19.

Lira, A. R. A. (2004) Caracterização em multiescala de análogos de reservatórios da Formação Maceó (Aptiano da Bacia de Alagoas), nas regiões de Japaratinga e Morros de Camaragibe $-A L$. Tese (Doutorado). Recife: Centro de Tecnologia e Geociências - UFP.

Lisle, R. J. L., Brabham, P. J., Barnes, J. W. (2014). Mapeamento Geológico básico: guia geológico de campo. $5^{\text {a }}$ ed. Porto Alegre: Bookman.
McKee, E. D., Crosby, E. J., Berryhill, H. L. (1967). Flood deposits, Bijou Creek, Colorado. Journal of Sedimentary Petrology, 37(3), 829-851. https://doi. org/10.1306/74D717B2-2B21-11D7-8648000102C1865D

Miall, A. D. (1999). Principles of sedimentary basin analysis. $3^{\text {a }}$ ed. Nova York: Spring-Verlag. https://doi. org/10.1007/978-3-662-03999-1

Miall, A. D. (2006). The Geology of Fluvial Deposits Sedimentary Facies, Basin Analysis, and petroleum Geology. Toronto: Springer. https://doi.org/10.1007/978-3-662-03237-4

Milani, E. J. (1997). Evolução Tectono-Estratigráfica da Bacia do Paraná e seu Relacionamento com a Geodinâmica Fanerozóica do Gondwana Sul-Ocidental. Tese (Doutorado). Porto Alegre: Instituto de Geociências - UFRGS.

Milani, E. J., Melo, J. G., Souza, P. A., Fernandes, L. A., França, A. B. (2007). Bacia do Paraná. Boletim de Geociências da Petrobras, 15(2), 265-287.

Milani, E. J., Ramos, V. A. (1998). Orogenias paleozoicas no domínio sul-ocidental do Gondwana e os ciclos de subsidência da Bacia do Paraná. Revista Brasileira de Geociências, 28(4), 473-484.

Milani, E. J., Zalán, P. V. (1999). An outline of the geology and petroleum systems of the Paleozoic interior basins of South America. Episodes, 22(3), 199-205. http://doi. org/10.18814/epiiugs/1999/v22i3/007

Morais Rego, L. F. (1930). A geologia do petróleo no Estado do Rio de Janeiro. Boletim do Serviço Geológico e Mineralógico, 46, 1-110.

Mutti, E. (1992). Turbidite sandstones. San Donato Milanese: AGIP - Istituto di Geologia Universitá di Parma.

Paim, P. S. G., Faccini, U. F., Netto, R. G. (2003). Geometria, arquitetura e heterogeneidades de corpos sedimentares (Estudo de Casos). São Leopoldo: Ponto e Virgula.

Pestilho, A. L. S., Monteiro, L. V. S., Oliveira, D. M., Santos Neto, E. V. (2018). Hyperpycnal-fed lacustrine turbidites in rift basins: Facies analysis and diagenesis of the Early Cretaceous Pendência Formation, Potiguar Basin, Brazil. Journal of South American Earth Sciences, 87, 4-24. https:// doi.org/10.1016/j.jsames.2017.10.015

Postma, G. (2014). Generic autogenetic behaviour in fluvial systems: lessons from experimental studies. In: A. W. Martinius, R. Ravnås, J. A. Howell, R. J. Steel, J. P. 
Wonham, editores. From Depositional Systems to Sedimentary Successions on the Norwegian Continental Margin, 46, 1-18. International Association of Sedimentology, Special Publication. https://doi.org/10.1002/9781118920435.ch1

Potter, P. E., Pettijohn, F. J. (1977). Paleocurrents and basin analysis. $2^{\mathrm{a}}$ ed. Nova York: Springer-Verlag. https://doi. org/10.1180/minmag.1979.043.325.36

Rodrigues, Y. C. (2015). Caracterização de arenitos de depósitos de efêmeros de unidades triássicas na região do Gráben Arroio Moirão, RS: potenciais análogos de reservatórios. Monografia (Graduação). Porto Alegre: Instituto de Geociências - UFRGS.

Salgado, E. T. (2016). Caracterização da distribuição faciológica das unidades Triássicas no Gráben Arroio Moirão através do cálculo de índices de proximidade e lateralidade: depósitos inundíticos gerados por fluxos hiperpicnais. Monografia (Graduação). Porto Alegre: Instituto de Geociências - UFRGS.

Santos, V. H. (2005). Sequência Siluro-Devoniana e Eocarbonifera da Bacia do Parnaiba, Brasil, como análogos para a explotação de hidrocarbonetos. Tese (Doutorado). Recife: Centro de Tecnologia e Geociências - UFP.

Seilacher, A. (1991). Events and their signatures - an Overview. In: G. Einsele, W. Ricken, A. Seilacher (Eds.), Cycles and events in stratigraphy, p. 222-226. Nova York: Springer-Verlag.

Soares, M. B., Schultz, C. L., Horn, B. L. D. (2011). New information on Riograndia guaibensis Bonaparte, Ferigolo and Ribeiro, 2001 (Eucynodontia, Tritheledontidae) from the Late Triassic of southern Brazil: anatomical and biostratigraphic implications. Anais da Academia Brasileira de Ciências, 83(1), 329-354. http://dx.doi.org/10.1590/ S0001-37652011000100021

Stow, D. A. V. (2005). Sedimentary rocks in the field: a color guide. Nova York: Academic Press.

Terry, R., Chilingar, G. (1955). Summary of: "Concerning some additional aids in studying sedimentary formations". Journal of Sedimentary Petrology, 25(3), 229-234. https:// doi.org/10.1306/74D70466-2B21-11D7-8648000102C1865D

Tucker, M. E. (2001). Sedimentary Petrology. $3^{\text {a }}$ ed. Oxford: Blackwell.
Tucker, M. E. (2014). Rochas Sedimentares: guia geológico de campo. $4^{\mathrm{a}}$ ed. Porto Alegre: Bookman.

Uliana, M. A., Biddle, K. (1988). Mesozoic-Cenozoic paleogeographic and geodynamic evolution of southern South America. Revista Brasileira de Geociências, 18(2), 172-190.

Walker, R. G. (1992). Facies, facies models and modem stratigraphic concepts. In: R. G. Walker \& N. P. James (Eds.), Facies Models: Response to Sea Level. Canadá: Association of Canada.

Wildner, W., Ramgrab, G. E., Lopes, R. C., Iglesias, C. M. F. (2005). Mapa geológico do Estado do Rio Grande do Sul. Escala 1:750.000. Porto Alegre: Companhia de Pesquisa de Recursos Minerais / Serviço Geológico do Brasil.

Williams, P. B., Kemp, P. H. (1971). Initiation of Ripples on Flat Sediment Beds. Journal of the Hydraulics Division, 97(4), 502-522.

Yang, R. Jin, Z., van Loon, A. J. T., Han, Z., Fan, A. (2017). Climatic and tectonic controls of lacustrine hyperpycnite origination in the Late Triassic Ordos Basin, central China: Implications for unconventional petroleum development. AAPG Bulletin, 101(1), 95-117. https://doi. org/10.1306/06101615095

Zavala, C., Arcuri, M. (2016). Intrabasinal and Extrabasinal turbidites: origin and distinctive characteristics. Sedimentary Geology, 337, 36-54. https://doi.org/10.1016/j. sedgeo.2016.03.008

Zavala, C., Arcuri, M., Di Meglio, M., Gamero Diaz, H., Contreras, C. (2011). A genetic facies tract for the analysis of sustained hyperpycnal flow deposits. In: R. M. Slatt, C. Zavala (Eds.), Sediment transfer from shelf to deep water - Revisiting the delivery system, 61, 31-51. AAPG Studies in Geology.

Zerfass, H. (2003). História tectônica e sedimentar do Triássico da Bacia do Paraná (Rio Grande do Sul, Brasil) e comparação geológica com as bacias de Ischigualasto e de Cuyo (Argentina). Tese (Doutorado). Porto Alegre: Instituto de Geociências - UFRGS.

Zerfass, H., Lavina, E. L., Schultz, C. L., Garcia, A. J. V., Faccini, U. F., Chemale Jr., F. (2003). Sequence stratigraphy of continental Triassic strata of Southernmost Brazil: a contribution to Southwestern Gondwana palaeogeography and palaeoclimate. Sedimentary Geology, 161(1-2), 85-105. 